\title{
Geologic Framework and Stratigraphy of Cretaceous and Tertiary Rocks of the Southern Ute Indian Reservation, Southwestern Colorado
}

ited States ological vey

fessional er 1505-B,C

ed in cooperation e Southern Ute nd the U.S.

of Intian Allairs

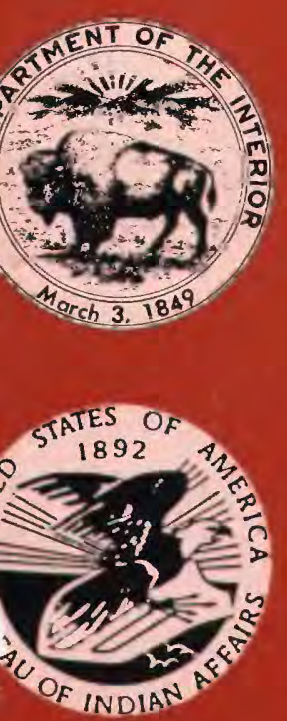

OE INDIAN

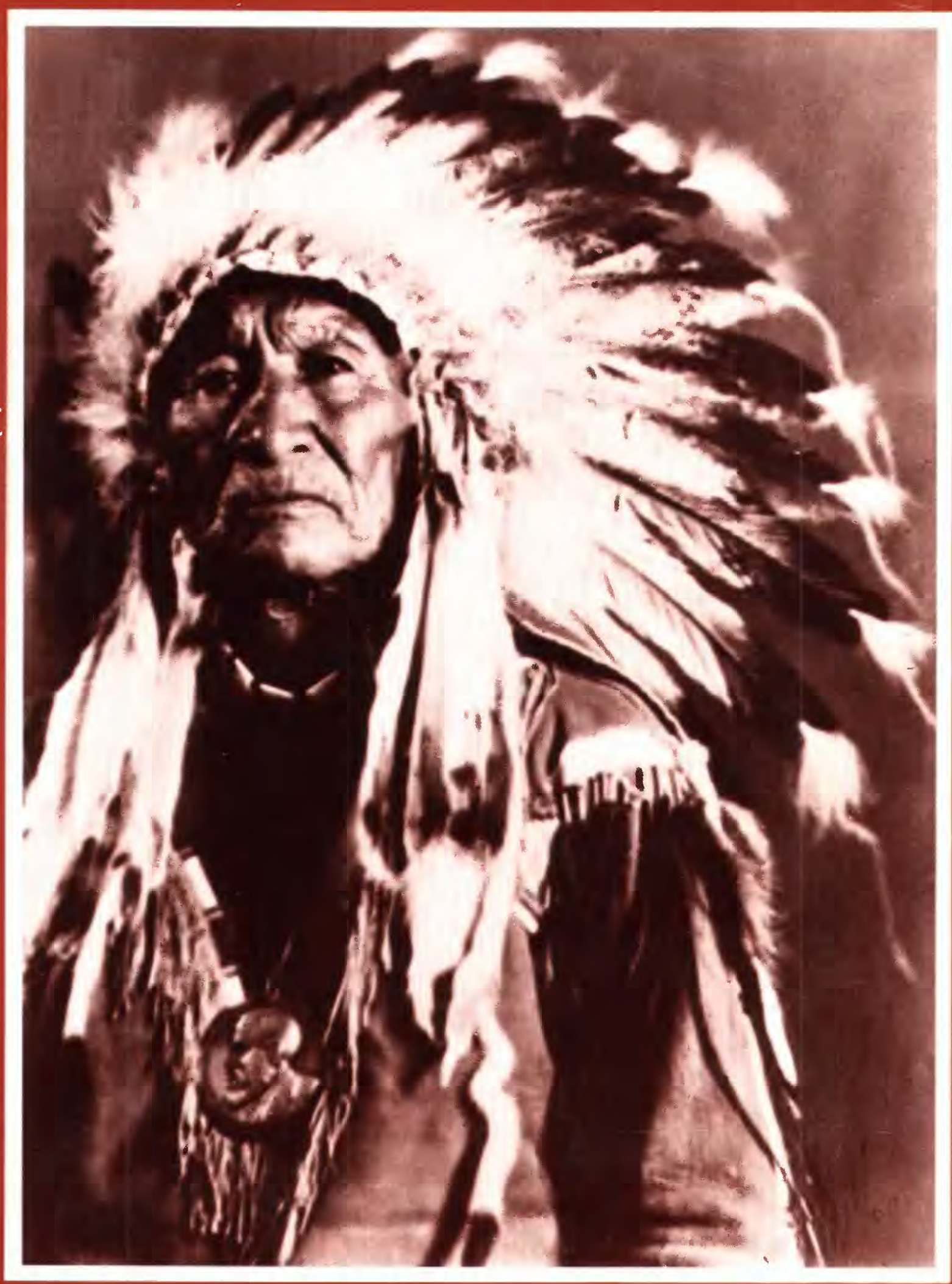




\section{COVER CAPTION}

COVER PHOTOGRAPH Chief Buckskin Charley (circa 1840-1936) was the last hereditary chief of the Utes. He was named Chief of the Utes at the request of Chief Ouray, under whom he had served as sub-chief for many years. He is wearing an 1890 Benjamin Harrison peace medal, which was the last medal designed specifically for presentation to Indians. The photograph is from the Lisle Updyke PhotoCollection of Dr. Robert W. Delany and is reprinted by permission of Dr. Robert W. Delany and Jan Pettit. 
Geologic Framework and Stratigraphy of Cretaceous and Tertiary Rocks of the Southern Ute Indian Reservation, Southwestern Colorado

B. Geologic Framework of Cretaceous and Tertiary Rocks in the Southern Ute Indian Reservation and Adjacent Areas in the Northern San Juan Basin, Southwestern Colorado

By WILLIAM M. AUBREY

C. Stratigraphic Cross Sections of Upper Cretaceous Rocks in the Northern San Juan Basin, Southern Ute Indian Reservation, Southwestern Colorado

By C.M. MOLENAAR and J.K. BAIRD

GEOLOGY AND MINERAL RESOURCES OF THE

SOUTHERN UTE INDIAN RESERVATION

Edited by ROBERT S. ZECH

U.S. GEOLOGICAL SURVEY PROFESSIONAL PAPER 1505-B,C

Chapters $B$ and $C$ are issued as a single

volume and are not available separately

UNited StATES GOVERNMENT PRINTING OFFICE, WASHINGTON : 1991 


\title{
U.S. DEPARTMENT OF THE INTERIOR
}

\author{
MANUEL LUJAN, JR., Secretary
}

\section{U.S. GEOLOGICAL SURVEY}

Dallas L. Peck, Director

\begin{abstract}
Any use of trade, product, or firm names in this publication is for descriptive purposes only and does not imply endorsement by the

U.S. Government
\end{abstract}

\section{Library of Congress Cataloging in Publication Data}

Geologic framework and stratigraphy of Cretaceous and Tertiary rocks of the Southern Ute Indian Reservation, Southwestern Colorado.

p. cm. - (Geology and mineral resources of the Southern Ute Indian Reservation ; B-C) (U.S. Geological Survey professional paper ; 1505-B-C)

Includes bibliographical references.

Contents: Geologic framework of Cretaceous and Tertiary rocks in the Southern Ute Indian Reservation and adjacent areas in the northern San Juan Basin, southwestern Colorado / by William M. Aubrey-Stratigraphic cross sections of Upper Cretaceous rocks in the northern San Juan Basin, Southern Ute Indian Reservation, southwestern Colorado / C.M. Molenaar and J.K. Baird.

1. Geology-Stratigraphic-Cretaceous. 2. Geology, Stratigraphic-Tertiary. 3. Geology-Colorado-Southern Ute Indian Reservation. I. Aubrey, William M. II. Molenaar, C.M. III. Baird, J.K. IV. Series. V. Series: Geology and mineral resources of the Southern Ute Indian Reservation; ch. B-C.

TN24.C6G46 Ch. B-C

[QE688]

$553^{\prime} .09788^{\prime} 29 \mathrm{~s}-\mathrm{dc} 20$

[551.7'7'0978829]

91-8070

CIP

For sale by the Books and Open-File Reports Section, U.S. Geological Survey, Federal Center, Box 25425, Denver, CO 80225 


\section{Geologic Framework of Cretaceous and Tertiary Rocks in the Southern Ute Indian Reservation and Adjacent Areas in the Northern San Juan Basin, Southwestern Colorado}

By WILLIAM M. AUBREY

GEOLOGY AND MINERAL RESOURCES OF THE

SOUTHERN UTE INDIAN RESERVATION

Edited by ROBERT S. ZECH

U.S. GEOLOGICAL SURVEY PROFESSIONAL PAPER 1505-B

Prepared in cooperation with the

Southern Ute Tribe and the

U.S. Bureau of Indian Affairs

Stratigraphy and depositional history of

Cretaceous and Tertiary rocks in

southwestern Colorado 



\section{CONTENTS}

Abstract

Introduction

Jurassic rocks

Brushy Basin Member of Morrison Formation

Lower Cretaceous rocks

Burro Canyon Formation

Sub-Dakota unconformity

Late Cretaceous transgressions and regressions

Upper Cretaceous rocks

Dakota Sandstone.....

Mancos Shale

Mesaverde Group

Point Lookout Sandstone

Menefee Formation

Cliff House Sandstone
Upper Cretaaceous rocks-Continued

Lewis Shale ................................................. B13

Pictured Cliffs Sandstone .................................... 14

Fruitland Formation .......................................... 14

Kirtland Shale ............................................... 15

Cretaceous-Tertiary boundary ....................................... 16

Tertiary rocks ....................................................... 16

Ojo Alamo Sandstone ......................................... 16

McDermott Member of Animas Formation ................... 17

Upper part of Animas Formation ............................. 18

Nacimiento Formation ...................................... 18

San Jose Formation ............................................. $\quad 20$

Tertiary igneous rocks ............................................ 21

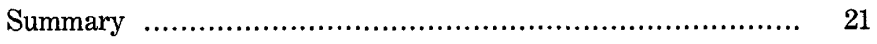

References cited ................................................. 21

\section{ILLUSTRATIONS}

FIgURE 1. Index map showing Southern Ute Indian Reservation and adjacent areas in southwestern Colorado and northwestern New Mexico

2. Nomenclature of uppermost Jurassic to Tertiary rock units in the vicinity of the Southern Ute Indian Reservation........

3. Map showing distribution of the Upper Jurassic Morrison Formation and Cretaceous formations that crop out on the Southern Ute Indian Reservation and adjacent areas in southwestern Colorado

4. Map showing Tertiary formations that crop out on the Southern Ute Indian Reservation and adjacent areas in southwestern Colorado.

5. Time-stratigraphic cross section showing Upper Cretaceous rocks in northwestern New Mexico and southwestern Colorado

6-8. Map showing positions of the western shoreline of the Western Interior seaway:

6. At times of maximum transgression during the Late Cretaceous

7. At times of maximum regression during the Late Cretaceous

8. During deposition of the upper part of the Dakota Sandstone during the middle and late Cenomanian

9. Diagrammatic cross section showing small-scale prograding packages of shoreline deposits in the Point Lookout Sandstone

10. Map showing trends of benches in the Cliff House Sandstone in northwestern New Mexico and southwestern Colorado

11. Cross section showing southeastward thinning of the Fruitland-Kirtland interval from the northwestern part of the San Juan basin to the southeastern part ....

12. Cross section showing stratigraphic relations of Upper Cretaceous and lower Tertiary rocks in the northwestern part of the San Juan basin

13. Map showing Tertiary geology of the San Juan basin 
Edited by Robert S. Zech

\title{
GEOLOGIC FRAMEWORK OF CRETACEOUS AND TERTIARY ROGKS IN THE SOUTHERN UTE INDIAN RESERVATION AND ADJACENT AREAS IN THE NORTHERN SAN JUAN BASIN, SOUTHWESTERN COLORADO
}

\author{
By William M. Aubrey
}

\begin{abstract}
Cretaceous and Tertiary rocks on the Southern Ute Indian Reservation in southwestern Colorado represent a variety of depositional environments. The sediments of the lower Cretaceous Burro Canyon Formation were deposited on an alluvial plain. Upper Cretaceous rocks consist of marine, coastal, and alluvial deposits that accumulated in or adjacent to the Western Interior seaway. A drop in sea level at the end of the Early Cretaceous caused streams to cut valleys into the top of the Burro Canyon, forming a regional unconformity. Regression of the Early Cretaceous sea was followed by a transgression into southwestern Colorado that resulted in the deposition of the fluvial, deltaic, and marginal-marine sediments of the Upper Cretaceous Dakota Sandstone and overlying marine Mancos Shale. The Mesaverde Group forms a generally northeasterly prograding deltaic and strand-plain wedge that intertongues with the upper part of the underlying Mancos and the lower part of the overlying marine Lewis Shale. The marginal-marine sediments of the Pictured Cliffs Sandstone, which overlie and interfinger with the upper part of the Lewis Shale, were deposited during the final regression of the Western Interior sea from southwestern Colorado near the end of Late Cretaceous time. The Pictured Cliffs is overlain by the alluvial, paludal, and lacustrine deposits of the uppermost Cretaceous Fruitland Formation and Kirtland Shale.

Tertiary rocks on the Reservation include parts of the Animas, Nacimiento, and San Jose Formations. These rocks, which are composed of sediments that are mostly fluvial in origin and have northerly sources, are the result of episodic uplift north of the San Juan basin during the early part of the Laramide orogeny. Tertiary dikes, sills,
\end{abstract}

Manuscript approved for publication, April 24, 1989. and stocks which are composed of basalt, diabase, and andesite, intrude the sedimentary rocks on the eastern side of the Reservation.

\section{INTRODUCTION}

At the request of the Southern Ute Tribe, the Energy and Minerals Division of the U.S. Bureau of Indian Affairs and the U.S. Geological Survey began a resource assessment program of tribal lands. This report, which is a part of that program, describes the history of Cretaceous and Tertiary sedimentary and igneous rocks that occur on the Southern Ute Indian Reservation (referred to as the "Reservation" in this report) in southwestern Colorado (fig. 1). A discussion of the Upper Jurassic Brushy Basin Member of the Morrison Formation is also included because stratigraphic relations between the Brushy Basin and the overlying Lower Cretaceous Burro Canyon Formation are uncertain in the Reservation area. The Brushy Basin and Cretaceous and Tertiary units are listed in figure 2; their locations on the Reservation and adjacent areas are shown in figures 3 and 4.

Cretaceous rocks on the Reservation contain important oil and gas, and coal resources. Oil and gas occur in the Dakota Sandstone, the Mancos Shale, the Tocito Sandstone Lentil of the Mancos Shale (the Gallup horizon of Pratt and Henkes, 1976), the Mesaverde Group, the Pictured Cliffs Sandstone, and the Fruitland Formation. Coal occurs primarily in the Menefee Formation of the Mesaverde Group and in the Fruitland Formation. 


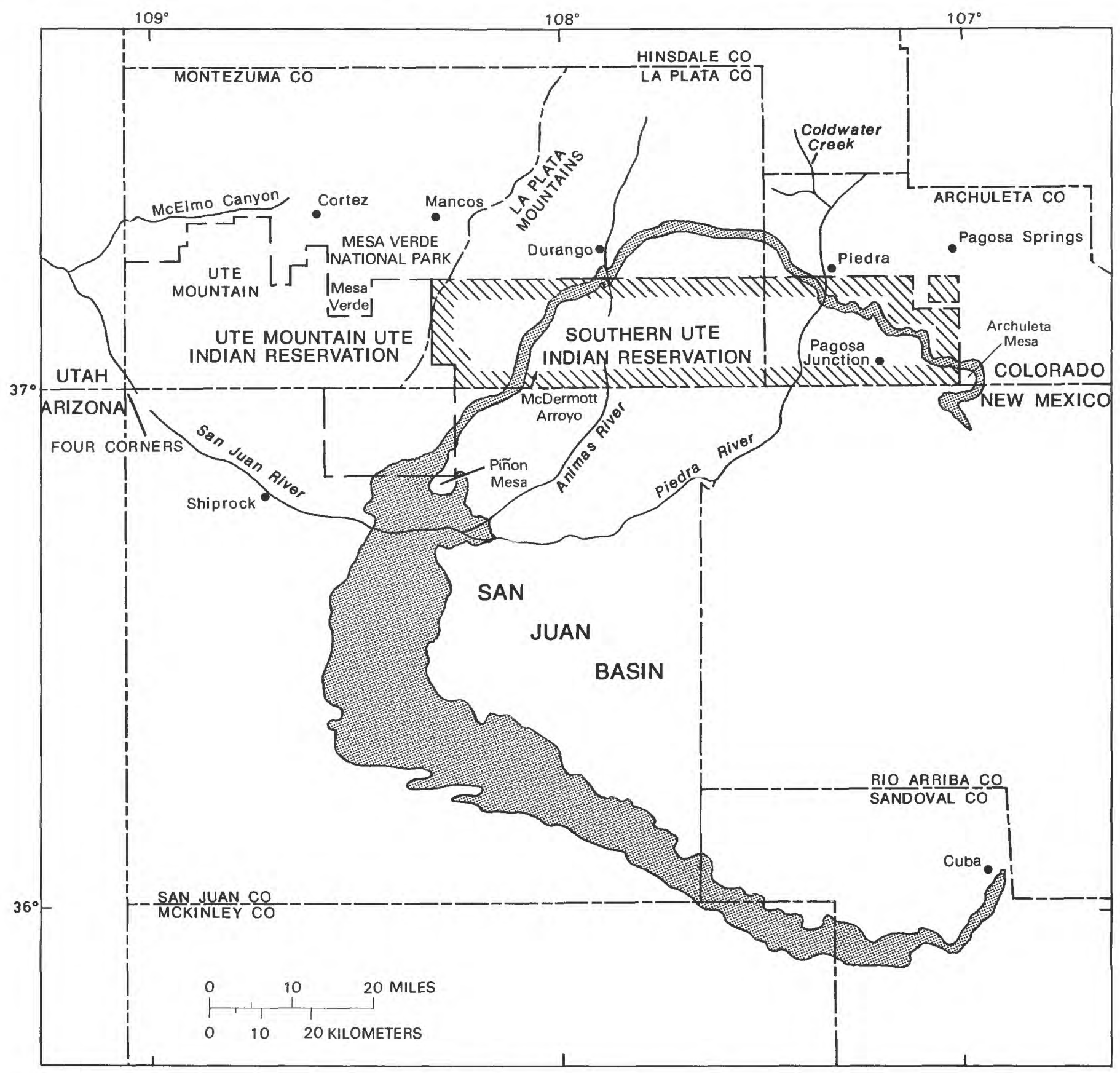

FIGURE 1. - Index map showing Southern Ute Indian Reservation and adjacent areas in southwestern Colorado and northwestern New Mexico. Shaded area is the outcrop of the combined Fruitland Formation and Kirtland Shale.

The Southern Ute Indian Reservation lies on the northern rim of the San Juan basin, which is a roughly circular depression in northwestern New Mexico and southwestern Colorado (fig. 1). Sedimentary rocks that fill the basin dip gently to the south from the Reservation area toward the center of the basin, which is located about $50 \mathrm{mi}(80 \mathrm{~km})$ southeast of Durango. Tertiary rocks occupy the central part of the Reservation (fig. 4), whereas Cretaceous rocks crop out along the western, eastern, and northern sides of the Reservation (fig. 3). All the geologic units described in this report crop out on the Reservation except for the Tocito Sandstone Lentil of the Mancos Shale and the Ojo Alamo Sandstone. Both the Tocito and the Ojo Alamo, however, may occur locally in the subsurface of the Reservation (Pratt and Henkes, 1976; Fassett, 1985). 


\begin{tabular}{|c|c|c|c|c|}
\hline ERA & SYSTEM & SERIES & & LITHOLOGIC UNIT \\
\hline \multirow{7}{*}{$\begin{array}{l}0 \\
0 \\
N \\
O \\
\text { 岕 } \\
0\end{array}$} & \multirow{2}{*}{ Tertiary } & Eocene & & San Jose Formation \\
\hline & & Paleocene & & $\begin{array}{l}\text { Upper Part of Animas } \\
\text { Formation / Nacimiento } \\
\text { Formation } \\
\text { Ojo Alamo Sandstone }\end{array}$ \\
\hline & $\begin{array}{l}\text { Cretaceous and } \\
\text { Tertiary }\end{array}$ & $\begin{array}{l}\text { Upper Cretaceous and } \\
\text { Paleocene }\end{array}$ & & $\begin{array}{l}\text { McDermott Member of } \\
\text { Animas Formation }\end{array}$ \\
\hline & \multirow{4}{*}{ Cretaceous } & \multirow{3}{*}{ Upper Cretaceous } & \multirow[b]{2}{*}{ 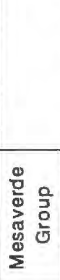 } & $\begin{array}{l}\text { Kirtland Shale } \\
\text { Fruitland Formation } \\
\text { Pictured Cliffs Sandstone } \\
\text { Lewis Shale }\end{array}$ \\
\hline & & & & $\begin{array}{l}\text { Clift House Sandstone } \\
\text { Menefee Formation } \\
\text { Point Lookout Sandstone }\end{array}$ \\
\hline & & & \multicolumn{2}{|r|}{$\begin{array}{l}\text { Mancos Shale } \\
\text { Dakota Sandstone }\end{array}$} \\
\hline & & Lower Cretaceous & \multicolumn{2}{|r|}{$\begin{array}{l}\text { Disconformity } \\
\text { Burro Canyon Formation }\end{array}$} \\
\hline 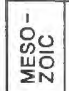 & Jurassic & Upper Jurassic & & $\begin{array}{l}\text { Brushy Basin Member of } \\
\text { Morrison Formation } \\
\text { (part) }\end{array}$ \\
\hline
\end{tabular}

FIGURE 2.-Nomenclature of uppermost Jurassic to Tertiary rock units in the vicinity of the Southern Ute Indian Reservation.

\section{JURASSIC ROCKS}

\section{BRUSHY BASIN MEMBER OF MORRISON FORMATION}

The Brushy Basin Member of the Upper Jurassic Morrison Formation constitutes the largest and oldest known playa-lake complex in the world (Turner-Peterson and others, 1986). It was deposited in a basin that extended $300 \mathrm{mi}(500 \mathrm{~km})$ from the southern edge of the present-day San Juan basin to north of the present-day Uncompahgre uplift and was about $185 \mathrm{mi}(300 \mathrm{~km})$ wide (Turner-Peterson and others, 1986). The part of the Brushy Basin Member that is on the Reservation was deposited in the west-central portion of this paleolake basin.

The Brushy Basin Member ranges from about 150 to $330 \mathrm{ft}(45-100 \mathrm{~m})$ thick in southwestern Colorado (Ekren and Houser, 1965) and consists predominantly of green or olive mudstone interbedded with tuff that contains abundant altered volcanic ash (Turner-Peterson and others, 1986). The ash came from a magmatic arc several hundred miles to the west. Salinity and alkalinity variations in the paleolake caused the ash in the lake deposits to alter differentially, which resulted in four concentrically zoned authigenic mineral facies (Bell,
1986; Turner-Peterson and others, 1986). Ash in tuff beds in mud flats around the perimeter of the lake altered to bentonite, whereas ash in succeeding zones, progressing toward the center of the lake, typically altered to clinoptilolite, analcime, and albite, respectively (Turner-Peterson and others, 1986).

Several of these authigenic mineral facies occur in the vicinity of the Reservation (Christine Turner-Peterson, oral commun., 1987). The Brushy Basin near the Reservation in the Durango and Piedra River areas occurs within the albite facies and was deposited within the more central part of the paleolake basin. The Brushy Basin in the McElmo Canyon area west of the Reservation was deposited nearer the western margin of the paleolake. The Brushy Basin at the eastern end of McElmo Canyon near Cortez is in the analcime facies and the boundary between the analcime facies, and the albite facies runs north-south somewhere between the Cortez and Durango areas. The Brushy Basin at the western end of McElmo Canyon is in the clinoptilolite facies, and the boundary between the clinoptilolite facies and the analcime facies runs north-south through the middle of the Ute Mountain area (Christine Turner-Peterson, oral commun., 1987).

Clinoptilolite beds are brick-orange, the analcime and albite beds are green or olive, and the bentonite beds are white. Beds that contain albite, analcime, and clinoptilolite also contain abundant authigenic silica; such beds form hard resistant layers. Preliminary data indicate that interbedded mudstone in the bentonite (mud flat) and clinoptilolite facies is generally smectitic, whereas the mudstone in the analcime and albite facies is generally more illitic (Christine Turner-Peterson, oral commun., 1986). Thin, resistant, very fine grained, silicified sandstone is common in the Brushy Basin Member (Ekren and Houser, 1965). Conglomeratic sandstone is uncommon, although a friable conglomeratic sandstone about $20 \mathrm{ft}(6 \mathrm{~m})$ thick occurs locally near the middle of the member (Ekren and Houser, 1965).

\section{LOWER CRETACEOUS ROCKS}

\section{BURRO GANYON FORMATION}

Lenticular conglomerate and conglomeratic fluvialchannel sandstone bodies at or near the top of the Brushy Basin Member in southwestern Colorado have been included in the Lower Cretaceous Burro Canyon Formation by Ekren and Houser $(1959,1965)$. These lenslike bodies are composed of quartzose sandstone and pebbles of colored chert, quartzite, silicified limestone, and siltstone. The conglomeratic sandstones are more numerous, less coarse, and more "blanketlike" in the upper 


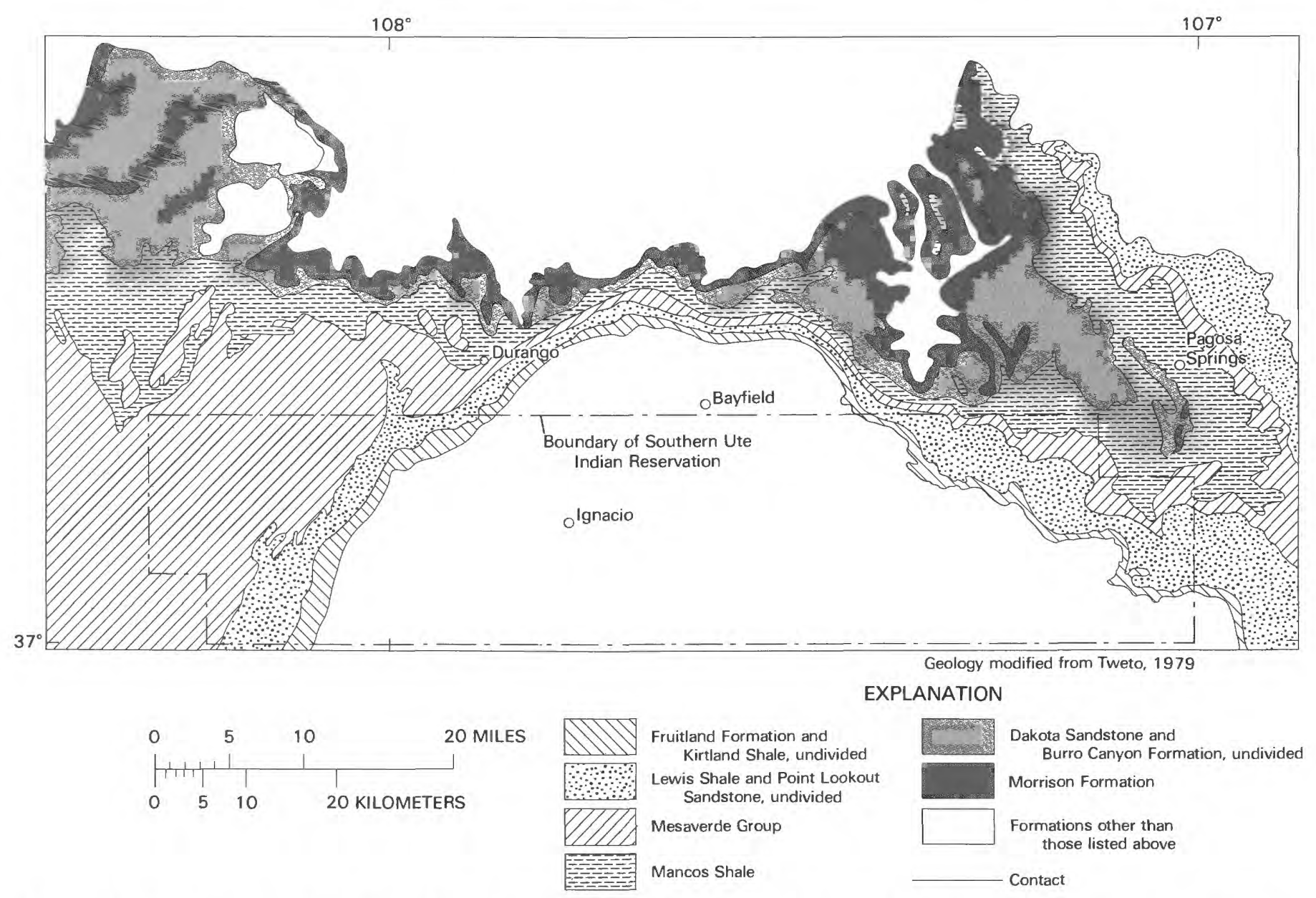

FIGURE 3.-Map showing distribution of the Upper Jurassic Morrison Formation and Cretaceous formations that crop out on the Southern Ute Indian Reservation and adjacent areas in southwestern Colorado.

part of the section than in the lower part. The lowest conglomerate is the Karla Kay Conglomerate Member, which crops out in the McElmo Canyon area west of the Reservation (Ekren and Houser, 1959). The Karla Kay forms a system of shoestring conglomerate and conglomeratic sandstone channel deposits that are rarely more than $2,000 \mathrm{ft}(610 \mathrm{~m})$ wide and $65 \mathrm{ft}(20 \mathrm{~m})$ thick (Ekren and Houser, 1959).

Mudstone in the Burro Canyon is most commonly green or olive. According to Ekren and Houser (1959, 1965), it is generally nonsmectitic and weathers "hackly" or "fissile" in contrast to the "frothy" weathering smectitic mudstone of the Brushy Basin Member of the Morrison Formation.

Ekren and Houser $(1959,1965)$ suggested that the lenticular conglomeratic sandstone of the Burro Canyon Formation is interbedded with both "hackly" weathering nonsmectitic mudstone of the Burro Canyon and "frothy" weathering smectitic mudstone of the Brushy Basin
Member. They placed the lower contact of the Burro Canyon at the base of the lowest conglomeratic sandstone or at the base of the lowest "hackly" weathering mudstone.

Stratigraphic relationships are more problematical, however, than those suggested by Ekren and Houser $(1959,1965)$. In the area of the Reservation, the mudstone of the Brushy Basin is part of the albite facies and is nonsmectitic. Therefore, it is difficult to distinguish from nonsmectitic mudstone of the Burro Canyon Formation, and the Brushy Basin-Burro Canyon boundary is uncertain. In McElmo Canyon, the Karla Kay and other stratigraphically low conglomeratic sandstone bodies interfinger with mudstones that contain bentonite beds, green hard beds, and possibly clinoptilolite typical of the Brushy Basin, and should probably be included in the Brushy Basin Member. More work is needed to define the relation between the Brushy Basin and the Burro Canyon in the region, however. 

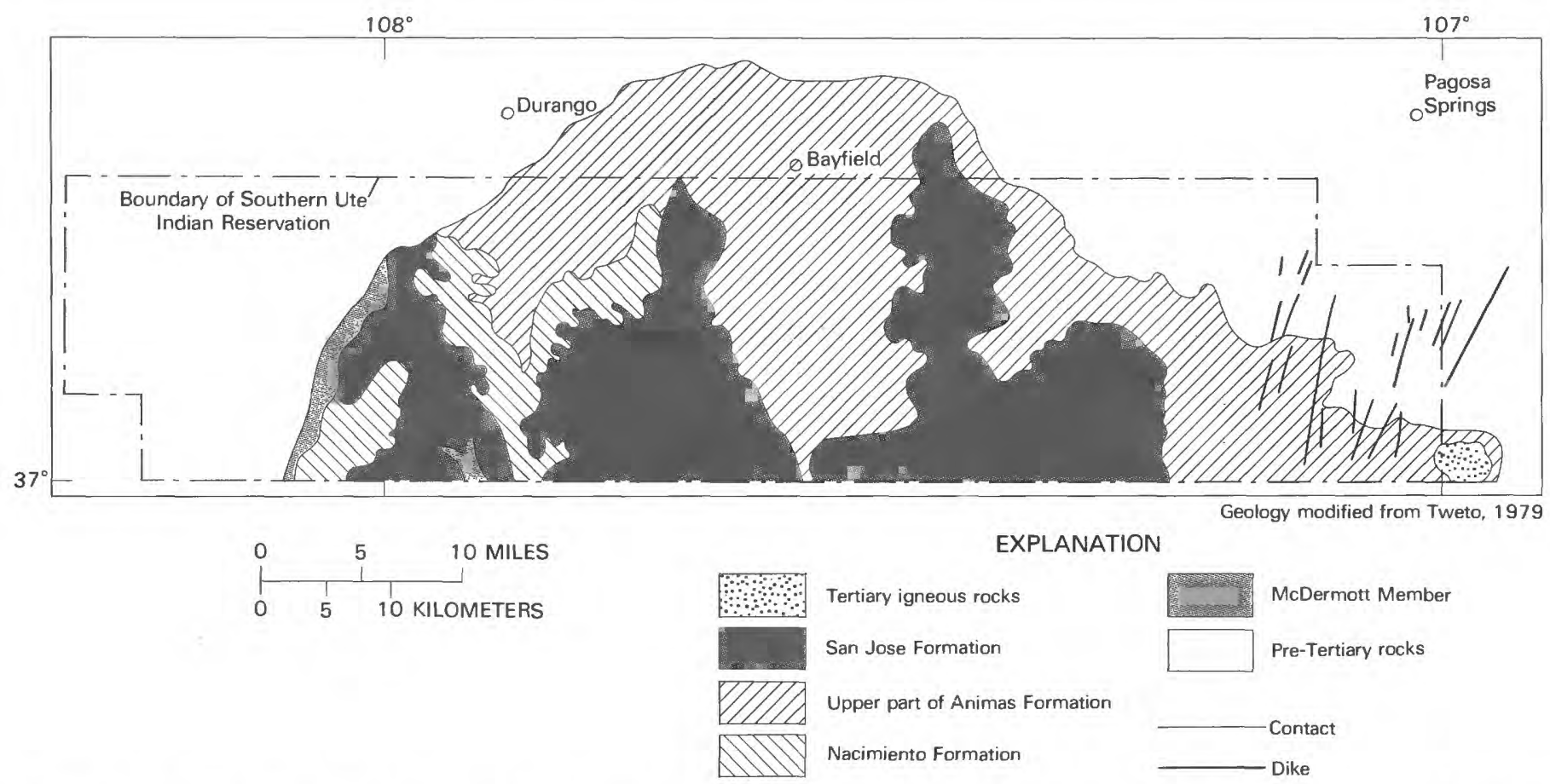

FIgURE 4.-Map showing Tertiary formations that crop out on the Southern Ute Indian Reservation and adjacent areas in southwestern Colorado.

\section{SUB-DAKOTA UNCONFORMITY}

The Burro Canyon Formation is separated from the overlying Dakota Sandstone by a disconformity in southwestern Colorado (Carter, 1957; Ekren and Houser, 1959). An incised drainage surface is preserved at this unconformity (Aubrey, 1986b). Depths of paleovalleys generally range from about 40 to $50 \mathrm{ft}$ (12-15 m) (Ekren and Houser, 1959) but are $100 \mathrm{ft}(30 \mathrm{~m})$ or more in some parts of the area (Carter, 1957; Aubrey, 1986a). These valleys are commonly several thousand feet wide (Carter, 1957) and generally have a northwesterly trend (Carter, 1957; Maxwell, 1976).

Paleovalleys with similar depths and widths probably occur in the subsurface of the Reservation. North of the Reservation near Piedra, the drainage surface is incised at least $40 \mathrm{ft}(12 \mathrm{~m})$ into the Burro Canyon Formation. Maximum depth and width of the valleys in the Reservation area are unknown, however, because of poor exposures.

Palynomorphs (Tschudy and others, 1984) indicate that the Burro Canyon is probably Aptian to early Albian (late Early Cretaceous) in age, although the uppermost part could be as young as late Albian. The basal Dakota is early Cenomanian (earliest Late Cretaceous). These ages suggest that the paleovalleys were cut during the Albian or early Cenomanian.

An eustatic drop in sea level is probably responsible for the incision that resulted in the disconformity
(Aubrey, 1986b, 1989). An epeiric sea lying to the east of the Colorado Plateau acted as base level for streams on the plateau. An eustatic lowering of sea level caused base level to drop, so that the streams degraded and cut the paleovalleys that are preserved at the unconformity. The sea-level drop corresponds in time with a third-order drop in global sea level that occurred 97 million years ago during the late Albian according to Vail and others (1977).

\section{LATE CRETACEOUS TRANSGRESSIONS AND REGRESSIONS}

The regression discussed above was followed by a transgression that inundated most of the Western Interior. This transgression initiated the first of five major transgressive-regressive cycles that are recorded in the Upper Cretaceous rocks in the southern Colorado Plateau region including the rocks on the Southern Ute Indian Reservation (Molenaar, 1983). Molenaar (1983) has numbered these cycles T-1/R-1 through T-5/R-5. They consist of generally southwesterly transgressing marine tongues separated by generally northeasterly prograding deltaic wedges (fig. 5). The cycles are Cenomanian to early Maastrichtian in age (fig. 5) (Molenaar, 1991).

Transgressive and regressive maxima for each cycle and their relation to the Reservation are shown in 


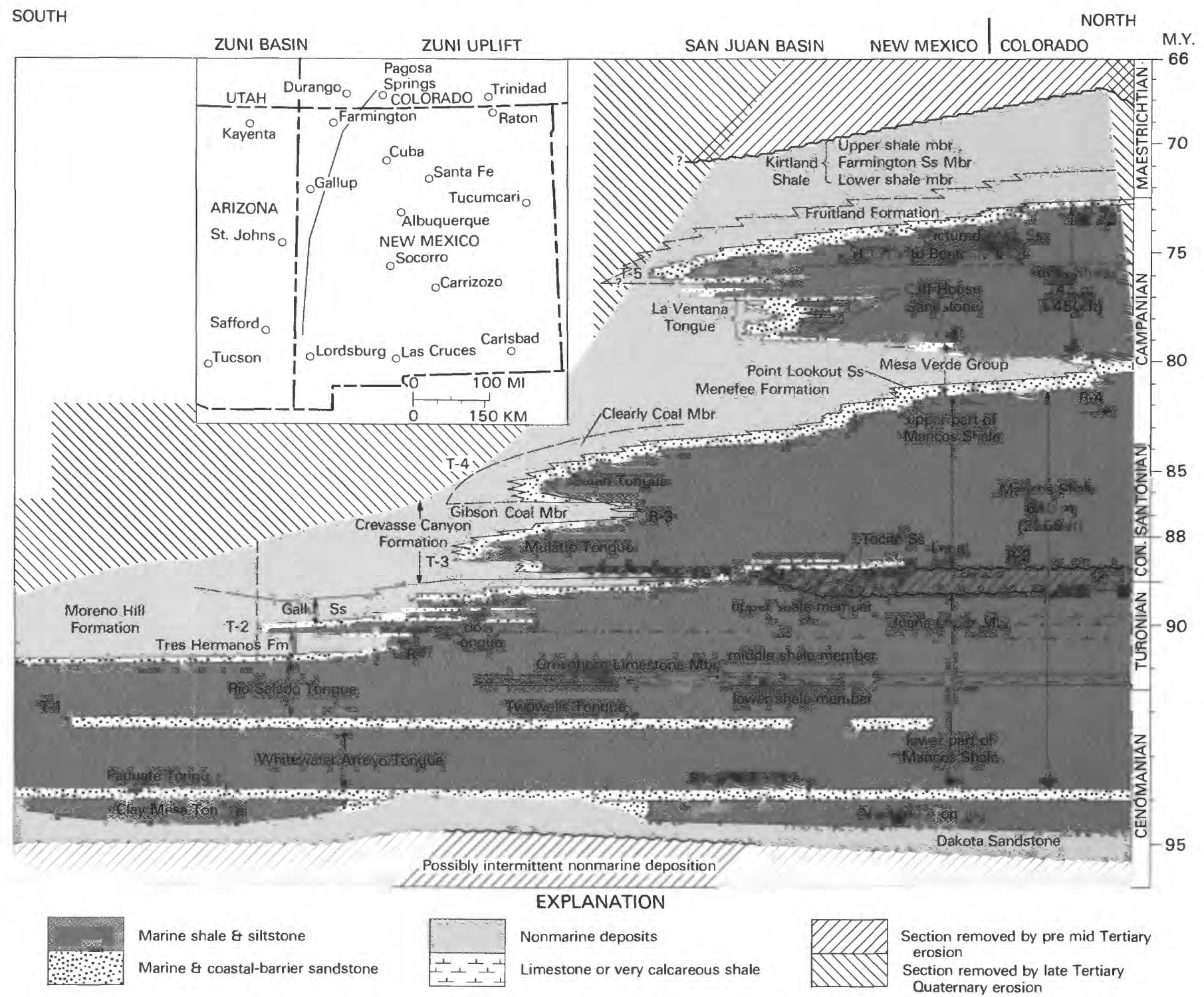

FigURE 5. - Time-stratigraphic cross section showing Upper Cretaceous rocks in northwestern New Mexico and southwestern Colorado. Cross section is modified from Molenaar (1983).

figures 6 and 7 (Molenaar, 1983). Shoreline trends were primarily northwest-southeast. The initial transgression (T-1) is the most extensive. Except during the R-4 and $\mathrm{R}-5$ regressions and the $\mathrm{T}-1$ and $\mathrm{T}-5$ transgressions, the shoreline was southwest of the Reservation. Transgressions and regressions of this shoreline, however, resulted in lithologic variations in marine rocks on the Reservation that will be discussed later in this report.

Hancock and Kauffman (1979) suggested that Cretaceous cyclothems in the Western Interior were caused by flucuations in eustatic sea level. Transgressiveregressive cycles in the southern Colorado Plateau, however, only correspond, in part, with cycles described by Hancock and Kauffman (1979) in other parts of the Western Interior (Molenaar, 1983). Factors other than sea level, such as changes in sediment supply and subsidence rates, may also be important (Pitman, 1978). Transgressive and regressive maxima of the different cycles (figs. 6, 7) are not synchronous throughout the southern Colorado Plateau (Molenaar, 1983) which indicates that, at least locally, factors other than sea level helped to control shoreline position. The T-2/R-2 cyclothem is not recognized in areas outside New Mexico and northeasternmost Arizona (Molenaar, 1983), which suggests that it formed independently of world-wide sea-level changes. 


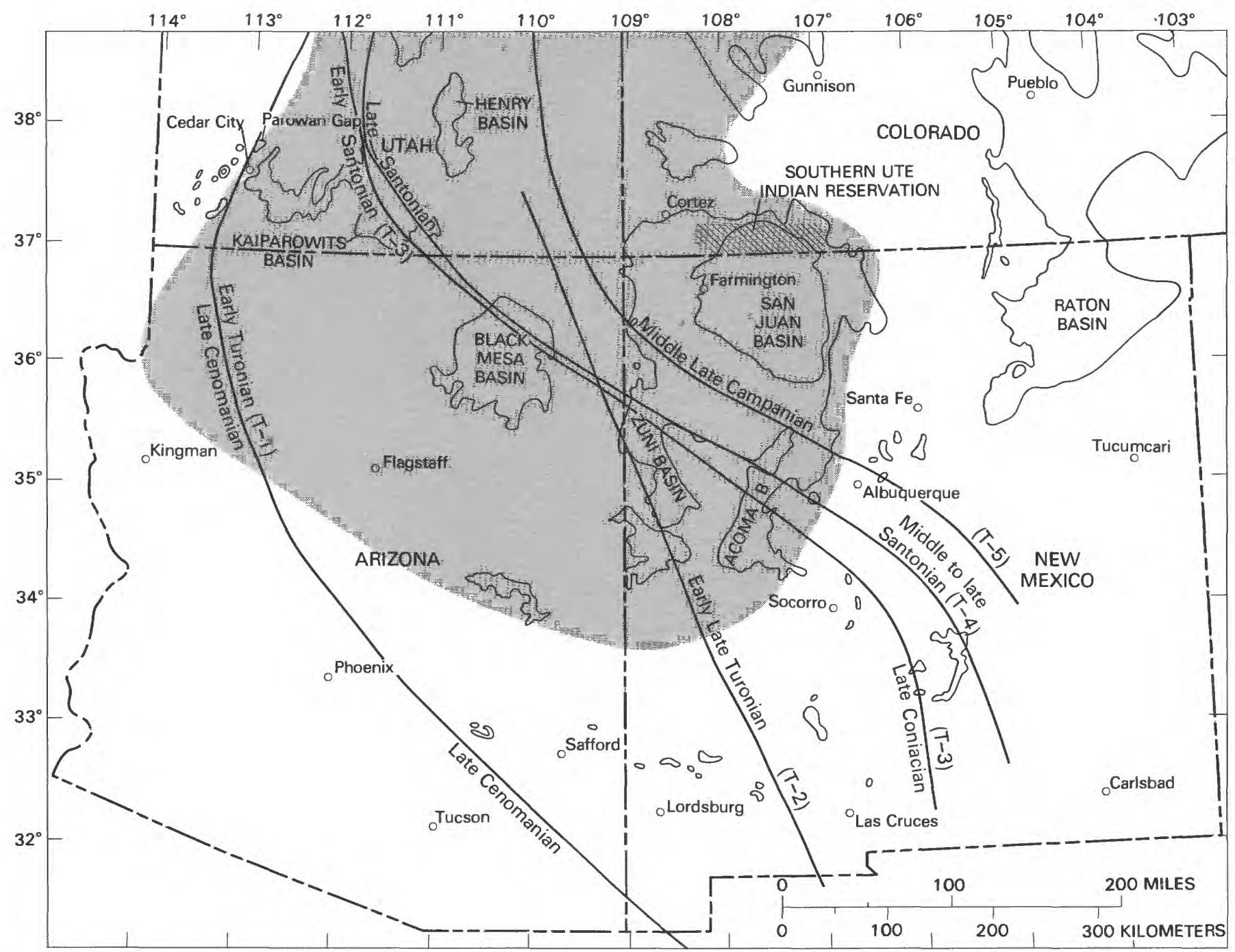

FIGURE 6. - Map showing positions of the western shoreline of the Western Interior seaway at times of maximum transgression during the Late Cretaceous. Shaded area is part of the Colorado Plateau. Map is modified from Molenaar (1983).

About $5,000 \mathrm{ft}(1,500 \mathrm{~m})$ of relative sea-level rise is necessary to accommodate the stratigraphic rise between the initial transgressive (T-1) marine deposits of the Dakota Sandstone and the final regressive (R-5) coastal-barrier sands of the Pictured Cliffs Sandstone (fig. 5) in the area of the Reservation. Subsidence is undoubtedly responsible for a large part of this apparent rise in sea level (Molenaar, 1983).

\section{UPPER CRETACEOUS ROGKS}

\section{DAKOTA SANDSTONE}

The Cenomanian Dakota Sandstone (Cobban and Hook, 1984; Tschudy and others, 1984) was deposited in response to the initial transgression (T-1) of the Upper
Cretaceous epeiric sea. The Dakota formed in a variety of environments and consists of a basal alluvial unit that is overlain by deltaic, marginal-marine, and marine rocks in different parts of the region.

The oldest unit of the Dakota Sandstone on the Reservation is the lower Cenomanian Encinal Canyon Member (Aubrey, 1986a). The Encinal Canyon consists of alluvial deposits that fill the valleys at the sub-Dakota unconformity. It was deposited by aggradation of Dakota streams in response to rising base level during the earliest stages of the T-1 transgression.

The Encinal Canyon Member is characteristically a trough-crossbedded, fine- to medium-grained sandstone that is commonly conglomeratic at its base. Tabularplanar crossbeds and, more rarely, horizontal or lowangle laminations also occur at some locations. The Encinal Canyon differs from the underlying Burro 


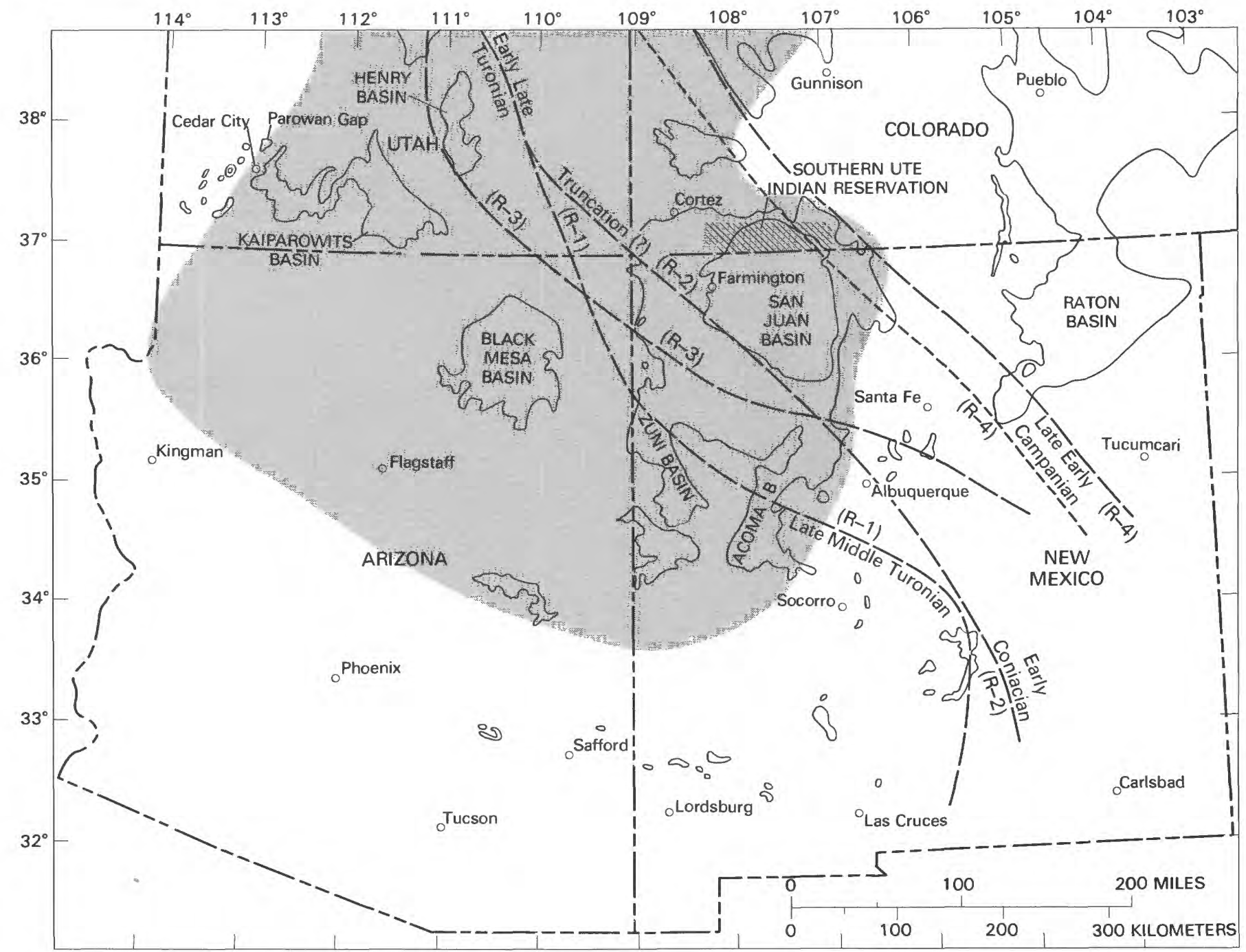

FIGURE 7.-Map showing positions of the western shoreline (long dashed lines) of the Western Interior seaway at times of maximum regression during the Late Cretaceous. Short dashed line shows seaward extent of the subaerial-plain deposits during the R-4 regression and is the approximate northern boundary of the Menefee Formation. Shaded area is part of the Colorado Plateau. Map is modified from Molenaar (1983).

Canyon Formation in several important aspects: (1) Carbonaceous material is scarce or absent in the Burro Canyon and common in the Dakota (Ekren and Houser, 1965; Aubrey 1986a). (2) Sandstone of the Encinal Canyon is light brown, whereas that of the Burro Canyon is generally white or buff. (3) Interbedded mudstones in the Dakota are gray or black, whereas those in the Burro Canyon are green or more rarely red.

Cobban and Hook (1984) used the distribution of various ammonite species to outline approximate shoreline positions during deposition of middle to upper Cenomanian Dakota rocks that overlie the Encinal Canyon Member (fig. 8). In general, Upper Cretaceous shorelines trended northwest-southeast and transgressed to the southwest. During the middle Cenomanian, however, a large embayment, the Seboyeta bay (Hook and others, 1980), formed in northwestern New Mexico. The shoreline on the northern side of this bay trended northeast-southwest and transgressed to the northwest toward the Reservation. The shoreline in the Reservation area trended north-south and transgressed to the west.

The Encinal Canyon Member is overlain by delta-plain deposits in the Four Corners area (west of the Reservation) and in the Durango area (north of the Reservation on the western side), by shore-zone deposits in the Coldwater Creek area (north of the Reservation on the eastern side), and by marine deposits in northwestern New Mexico (south of the Reservation). This distribution of depositional environments is consistent with the shoreline trends (fig. 8) proposed by Cobban and Hook (1984). North-south shoreline trends suggest that 


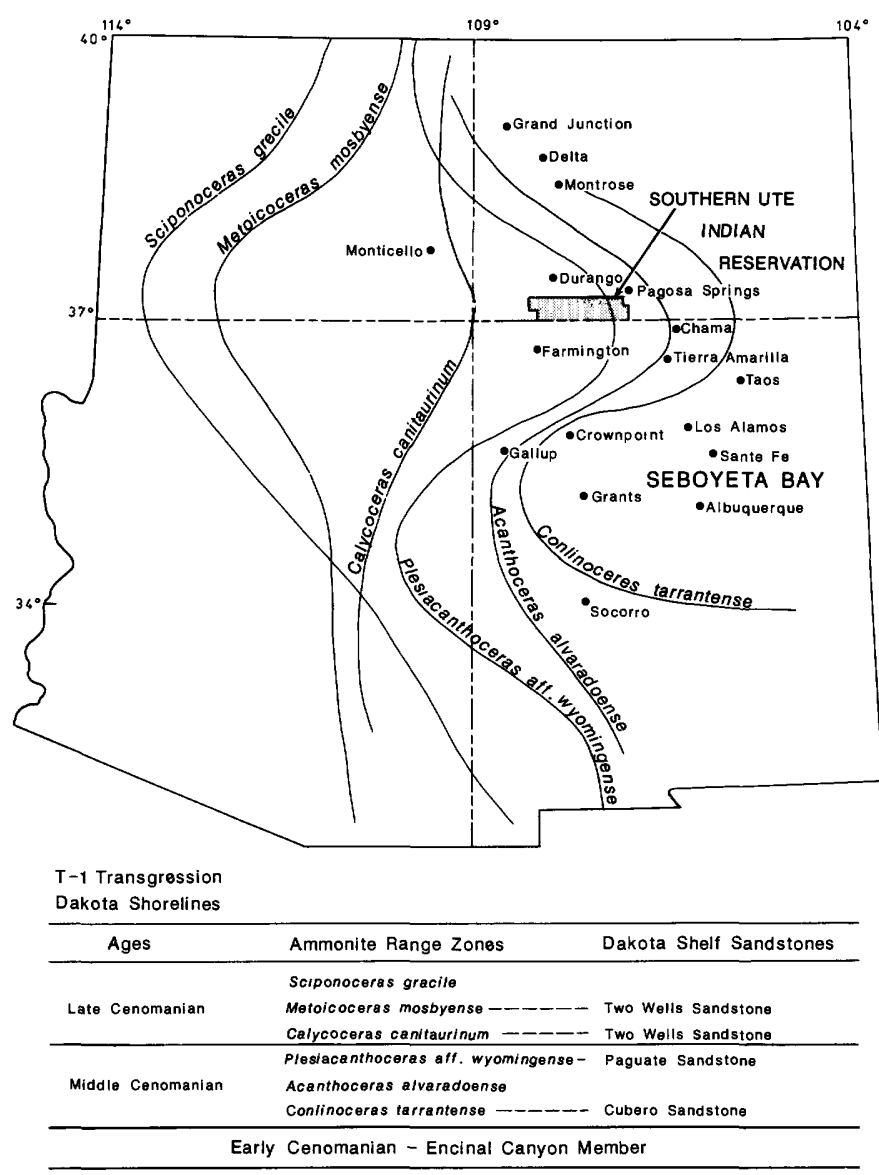

FIGURE 8.-Map showing positions of the western shoreline of the Western Interior seaway during deposition of the upper part of the Dakota Sandstone during the middle and late Cenomanian. Shoreline trends are based on the distribution of ammonite fossils found in the lower part of Mancos Shale which interfingers with the Dakota Sandstone. Map is modified from Cobban and Hook (1984).

depositional environments in the subsurface on the Reservation are similar to those in the Durango and Coldwater Creek areas north of the Reservation.

Delta-plain rocks in the Four Corners area consist of a lenticular, stacked-channel sandstone facies and a finegrained overbank facies. The channel deposits are fineto medium-grained, commonly trough crossbedded sandstones. The fine-grained overbank deposits consist of gray to dark-gray carbonaceous mudstone and coal. The coal beds are not persistent and range from a few inches to $3 \mathrm{ft}(0.9 \mathrm{~m})$ in thickness (Ekren and Houser, 1965). In the Durango area, channel deposits consist of tabularplanar-crossbedded, fine-grained sandstone. More work is needed to determine the extent of thin coals that occur in the Durango area.

In the Coldwater Creek area, the Encinal Canyon Member is overlain by sandstone, siltstone, mudstone, and coal that were deposited in a variety of shore-zone environments. The sandstone, which is commonly fine grained, bioturbated, and flat bedded or ripple laminated, was probably deposited in tidal-flat, shoreface, or offshore-bar environments. Coal may have been deposited in coastal swamps, and siltstone and mudstone may represent lagoonal or offshore environments.

Deltaic rocks in the western part of the Reservation and shore-zone rocks in the eastern part are probably lateral equivalents, deposited during a stillstand of the shoreline. The Dakota Sandstone is a transgressive sequence in the Reservation area; the fluvial rocks of the Encinal Canyon are overlain by deltaic rocks and shorezone rocks that are in turn overlain by the marine Mancos Shale.

Marine strata that compose the upper part of the Dakota in northwestern New Mexico consist of several locally discontinuous shelf sandstones that intertongue with marine (Mancos) shale. In ascending order the shelf sandstones are the Cubero, Paguate, and Twowells Tongues of the Dakota Sandstone (Landis and others, 1973). The Cubero and Paguate are middle Cenomanian in age and are restricted to the area of the Seboyeta bay. The bay expanded during the middle Cenomanian so that the Paguate Tongue occurs in a larger area than the next lower sandstone, the Cubero Tongue (fig. 8) (Hook and others, 1980). The Twowells Tongue, which is late Cenomanian in age, occurs locally in eastern Utah and Arizona and southwestern Colorado, as well as in northwestern New Mexico.

\section{MANCOS SHALE}

The Mancos Shale in the Reservation includes all the rocks between the transgressive Dakota Sandstone (T-1) and the regressive Point Lookout Sandstone (R-4) (fig. 5 ) and consists of about $1,900 \mathrm{ft}(590 \mathrm{~m})$ of generally gray to dark-gray, gypsiferous, marine shale (Ekren and Houser, 1965). The Mancos Shale, however, is not homogenous. Changes in lithology within the Mancos in the Reservation area reflect transgressions and regressions of the shoreline that occurred to the southwest (Lamb, 1973).

A regional unconformity of Coniacian age divides the Mancos Shale into upper and lower parts in the area of the Reservation (fig. 5) (Dane, 1960). The lower part can be further subdivided into a lower shale member, the Bridge Creek Limestone Member (formerly the Greenhorn Limestone Member) (Ekren and Houser, 1965; Huffman, 1987; Kirk and others, 1988), and middle and upper shale members (lower and upper Carlile beds of Lamb, 1973), separated by the Juana Lopez Member 
(Lamb, 1973; McCubbin, 1969; Rankin, 1944). The Bridge Creek Limestone Member of the Mancos in the Reservation area is equivalent to part of the Bridge Creek Member of the Greenhorn Limestone in southeastern Colorado (Cobban and Hook, 1984) and that the lower shale member is equivalent to the Hartland Member of the Greenhorn Limestone (Sageman, 1985).

The lower shale member, which occurs between the Dakota Sandstone and the Bridge Creek Limestone Member, is about $75-100 \mathrm{ft}(23-30 \mathrm{~m})$ thick on the northern side of the San Juan basin (Ekren and Houser, 1965; Wanek, 1959). West of the Reservation in the Four Corners area, the member grades from a medium-gray carbonaceous shale in its lower part to a medium-gray calcareous shale in its upper part (Lamb, 1973). Near Pagosa Springs at the northeastern corner of the Reservation, the lower shale member is medium to olive gray and calcareous throughout (Lamb, 1973). The Pagosa Springs section is more calcareous than the Four Corners section partly because it is more distal from the transgressing Dakota shoreline (T-1) (fig. 6). The upward increase in the calcareousness of the shale in the Four Corners area reflects the increase in distance from the transgressing shoreline with time.

The calcareous beds in the upper part of the lower shale member grade upward into the Bridge Creek Limestone Member. Limestone development in the Bridge Creek is at least partly a function of distance from shore. The Bridge Creek in the Shiprock area southwest of the Reservation consists of a few thin limestone beds in a predominantly shaly section. In the northeastern part "of the Reservation near Pagosa Springs, the Bridge Creek contains about $14 \mathrm{ft}(4.3 \mathrm{~m})$ of mostly thick bedded limestone, and the shale is more calcareous (Lamb, 1973). Limestone in the Bridge Creek is dense and locally almost lithographic (Ekren and Houser, 1965). The limestone weathers to light gray or white and locally contains Pycnodonte newberryi (Stanton) shells.

The Cretaceous sea probably reached its maximum extent during Greenhorn time (Eicher, 1969), and the Bridge Creek Limestone Member was probably deposited near the peak of the T-1 transgression. The shift from the $T-1$ transgression to the $R-1$ regression in the northern San Juan basin is recorded in the middle shale member, which overlies the Bridge Creek (Lamb, 1973). The lower part of the middle shale member, which was deposited during the transgression, is very calcareous. The shift to the regression, however, was accompanied by an increase in clastic sedimentation, and the upper part of the middle shale member, which was deposited during the regression, is more argillaceous and coarser grained than the lower part. The shift from transgression to regression is also marked by an abrupt change in foraminiferal fauna. The transgressive suite of fauna is calcareous and abundant, whereas the regressive suite is arenaceous and sparse (Lamb, 1973).

The middle shale member is about $355 \mathrm{ft}$ (108 m) thick near Shiprock. It thins gradually in the seaward direction and is about $230 \mathrm{ft}(70 \mathrm{~m})$ thick in the Pagosa Springs area (Lamb, 1973). Thinning of the middle shale member occurs mostly within the lower calcareous part, which ranges from over $100 \mathrm{ft}(30 \mathrm{~m})$ thick at Shiprock to less than $15 \mathrm{ft}(4.5 \mathrm{~m})$ thick at Pagosa Springs, and probably reflects reduced clastic deposition with increased distance from the transgressing shoreline. The upper argillaceous part, which was deposited during the regression, maintains a more constant thickness and composes a thicker portion of the section than the underlying calcareous rocks (Lamb, 1973).

The Juana Lopez Member consists of thin, fine- to coarse-grained calcarenite, which is composed of bioclastic debris (Nummedal and others, 1986), and interbedded shale, siltstone, and fine-grained sandstone (Molenaar, 1990). It is a rather resistant unit and commonly forms conspicuous ridges that separate the less resistant slopeforming beds of the middle and upper shale members (Lamb, 1973). The Juana Lopez is a condensed section that marks the period of most rapid rise in relative sea level during the T-2 transgression (Nummedal and others, 1986). During the sea-level rise, lagoons and estuaries trapped sediment in coastal areas, and the rate of sediment input to the shelf decreased. Sediment on the shelf was then reworked by storm waves and currents, and bioclastic material was concentrated into the calcarenite beds.

The Juana Lopez is one of the most laterally persistent Cretaceous units in the southern Rocky Mountain region (Nummedal and others, 1986). It is better developed, however, in the western and southern parts of the northern San Juan basin than in the eastern part. In the Four Corners area, the Juana Lopez is about $40 \mathrm{ft}(12 \mathrm{~m})$ thick and is composed of very fossiliferous, finely crystalline, pale-yellow-gray limestone and interbedded dark-gray fissile mudstone (Ekren and Houser, 1965). It becomes more shaly to the east, and near Pagosa Springs it consists of only some platy limestone beds (Lamb, 1973). The Juana Lopez is a slope former in the Pagosa Springs area where it cannot be readily differentiated from the middle and upper shale members. In general the Juana Lopez is gradational with the underlying middle shale member, and the basal contact is placed at the base of the lowermost prominent limestone bed (Ekren and Houser, 1965). 
The upper shale member, which overlies the Juana Lopez, is $165 \mathrm{ft}(50 \mathrm{~m})$ thick in the vicinity of Shiprock (Lamb, 1973). The upper shale member, however, is truncated by the Coniacian unconformity in the seaward direction so that it is thin or absent in the vicinity of the Reservation and in the Four Corners area (Lamb, 1973).

The basal-Niobrara-equivalent Tocito Sandstone Lentil of the Mancos Shale crops out on the western side of the San Juan basin to the west and south of the Reservation (Lamb, 1973). It rests unconformably on the upper shale member (and the Gallup Sandstone) in the south and on the Juana Lopez in the north (Ekren and Houser, 1965). Deposition of the Tocito was probably controlled by erosional irregularities on the underlying Coniacian unconformity (Lamb, 1973). Sharp breaks in slope coincide with thick, massive sandstones. Intervals between scarps are composed of many thin, platy sandstone beds interbedded with sandy shale (Lamb, 1973).

The Tocito Sandstone Lentil was deposited during the T-3 transgression (Molenaar, 1983). Some workers interpreted thick sandstones in the Tocito to represent offshore-bar deposits (Lamb, 1968; Campbell, 1971). Lamb (1968) suggested that breaks in slope that control sand deposition were the result of shoreline erosion and that some of the offshore bars may be reworked shoreface and beach deposits.

The Tocito Sandstone Lentil crops out as far north as the Ute Mountain area on the western side of the basin (Lamb, 1973; Ekren and Houser, 1965). Although it does not crop out on the Reservation, it may occur locally in the subsurface (the "Gallup horizon" of Pratt and Henkes, 1976).

Approximately $1,500 \mathrm{ft}$ of Mancos Shale overlies the Coniacian unconformity. The $400-500 \mathrm{ft}$ of shale directly above the unconformity has variable carbonate content. The remainder is less calcareous, and in its upper part, grades into the overlying Point Lookout Sandstone (Molenaar, 1990).

\section{MESAVERDE GROUP}

The Campanian Mesaverde Group, which overlies the Upper Mancos Shale, was deposited during the R-4 regression and the T-5 transgression (Molenaar, 1983) (fig. 5). The Mesaverde, which consists of the marginalmarine Point Lookout Sandstone, the nonmarine Menefee Formation, and the marginal-marine Cliff House Sandstone, forms a northwest-southeast-striking tongue that extends northeastward into the marine deposits of the Mancos and Lewis Shales (fig. 5) (Molenaar, 1983). The $R-4$ regression is the oldest of the Cretaceous regressions in the San Juan basin to extend northward into the area of the Reservation (fig. 7). The three formations that make up the group are discussed in greater detail below.

\section{POINT LOOKOUT SANDSTONE}

The Point Lookout Sandstone at the base of the Mesaverde Group conformably overlies and is transitional with the Mancos Shale. In the area of the Reservation the Point Lookout is divided into a lower sandstone and shale member and an upper massive sandstone member (Wanek, 1959). The sandstone and shale member is composed of interbedded yellowishgray, fine-grained, cross-laminated sandstone and sandy dark-olive-gray, fossiliferous shale; the amount of sand in the member increases upward toward the overlying massive sandstone member. The lower sandstone and shale member is about $80-125 \mathrm{ft}(25-38 \mathrm{~m})$ thick in the Mesa Verde area (Wanek, 1959). Elsewhere in the northern part of the basin it is as thick as $250 \mathrm{ft}(76 \mathrm{~m})$ (Zapp, 1949; Barnes and others, 1954). The upper massive sandstone member in the Mesa Verde area consists of thick to massive beds of light-gray to yellowish-gray, crossbedded, fine- to medium-grained sandstone that is about $200-250 \mathrm{ft}(61-76 \mathrm{~m})$ thick (Wanek, 1959).

The Point Lookout Sandstone rises stratigraphically (fig. 5) from the southwest to the northeast (Hollenshead and Pritchard, 1961; Molenaar, 1983) and grades laterally as well as vertically into both the underlying Mancos Shale and overlying Menefee Formation. The Point Lookout Sandstone was deposited in a variety of coastal, shoreline environments (Wright, 1986; Zech, 1982; Devine, 1980; Sheitiwy, 1978). Figure 9 shows a typical prograding package of shoreline deposits in which the offshore transition zone corresponds to Wanek's (1959) sandstone and shale member, and the lower shoreface, upper shoreface, and foreshore zones correspond to his massive sandstone member.

The regressive-transgressive $(\mathrm{R}-4 / \mathrm{T}-5)$ cycle represented by the Mesaverde Group is approximately equivalent in scale to third-order cycles of Vail and others (1977) (Wright, 1986). Progradation of the Point Lookout Sandstone probably consisted of a series (fig. 9) of smaller scale transgressive-regressive cyclic events (Wright, 1986). Because each successive small-scale transgression generally did not extend as far landward as the previous transgression, the overall effect was that of regression of the shoreline to the northeast (Wright, 1986). Hollenshead and Pritchard (1961) recognized benches or abrupt stratigraphic rises in the Point 


\section{POINT LOOKOUT-STYLE PROGRADATION}

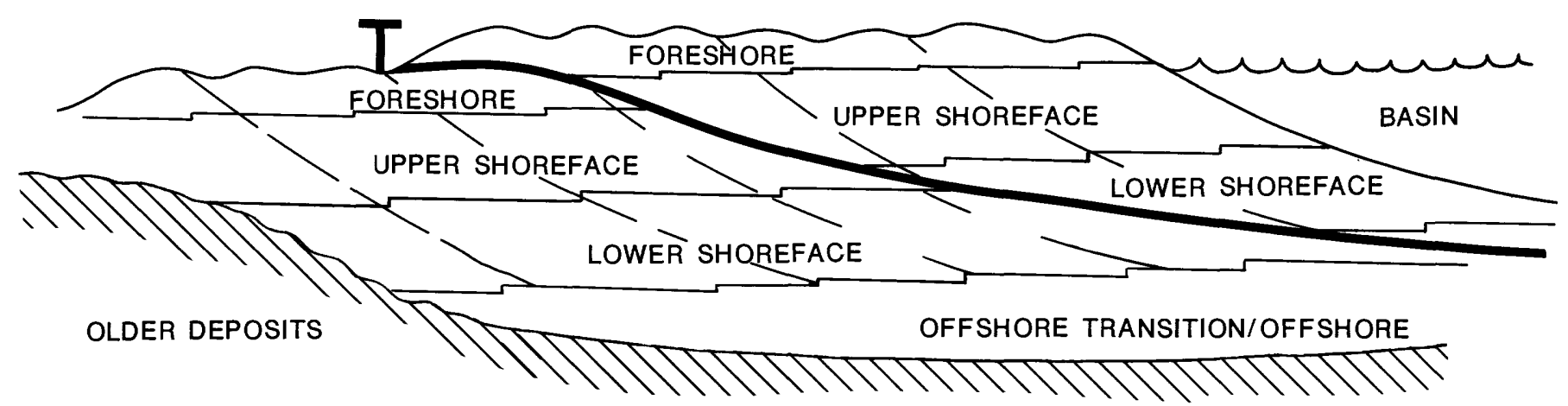

FIGURE 9. - Diagrammatic cross section showing small-scale prograding packages of shoreline deposits in the Point Lookout Sandstone separated by planar transgressive erosion surfaces (T). Because each succeeding transgression does not extend as far landward as the previous transgression, the overall effect is one of regression of the shoreline. The cross section is from Wright (1986).

Lookout (fig. 5) that probably represent stacking of small-scale, transgressive-regressive, cyclic deposits during a time when the shoreline was relatively stable (Wright, 1986). Benches in the northwestern San Juan basin form thick sandstone bodies that continue for many miles in a northwest-southeast direction (Hollenshead and Pritchard, 1961).

\section{MENEFEE FORMATION}

The Menefee Formation, which overlies the Point Lookout Sandstone, consists of shale, carbonaceous shale, coal, and siltstone alternating with lenticular beds of sandstone (Irwin, 1966). The sandstone is gray to grayish orange, fine to medium grained, and quartzose and commonly forms thick lenticular beds that grade laterally into shale and siltstone. The shale is dark gray and generally sandy. The carbonaceous shale, which is generally associated with coal, is dark brown.

The Menefee thins to the northeast and pinches out in the eastern part of the Reservation. West of the Reservation, the Menefee ranges in thickness from about $800 \mathrm{ft}$ $(245 \mathrm{~m})$ near the Colorado-New Mexico State line to about $340 \mathrm{ft}(103 \mathrm{~m})$ in the northern part of the Mesa Verde area (Wanek, 1959). The approximate northern boundary of Menefee deposition is shown in figure 7. In areas where the Menefee is absent, Point Lookout Sandstone and Cliff House Sandstone equivalents are undivided and form the Mesaverde Formation.

Hayes and Zapp (1955) and Wanek (1959) have subdivided the Menefee in the vicinity of the western part of the Reservation into a lower coal member, a middle barren member, and an upper coal member. Coal beds in the lower part of the formation are lenticular, extend for several miles, and have a maximum thickness of about
$4 \mathrm{ft}(1.2 \mathrm{~m})$. Those in the upper coal member are very lenticular and variable in thickness, with a maximum thickness of about $6 \mathrm{ft}(1.8 \mathrm{~m})$. Coal beds in the middle barren unit are very thin, discontinuous, and impure (Wanek, 1959). Total thickness of coal beds in the Menefee in the subsurface in the northern part of the San Juan basin does not exceed about $10 \mathrm{ft}(3 \mathrm{~m})$ (Whyte and Shomaker, 1977).

The Menefee Formation was deposited in a variety of depositional environments. Relatively thick, lenticular, crossbedded sandstones in the Menefee are probably channel sandstones deposited by meandering streams; thin sandstone beds represent crevasse-splay or levee deposits; and shale and coal beds represent nonchannel floodplain deposits (Siemers and Wadell, 1977). Coalbearing portions (the lower and upper members) of the Menefee were probably deposited on the middle or lower part of a delta plain where increased subsidence, decreased sand deposition, and abundant organic material resulted in extensive coal development (Siemers and Wadell, 1977). Barren portions (the middle member) of the Menefee, on the other hand, were probably deposited on a continental fluvial plain or on the upper to middle part of a delta plain where conditions were not as conducive to coal development. Beaumont and others (1971) suggested that coal beds in the upper part of the Menefee were deposited in a lagoonal or paludal environment. A lagoonal-paludal model, however, does not explain the presence of channel sandstones that are common in the upper part of the Menefee or the absence of brackish-water fossils in the Menefee (Siemers and King, 1974). According to Beaumont and others (1971), the thickest coal beds in the Menefee occur behind stacked shoreline deposits (the benches of Hollenshead 
and Pritchard, 1961) that were deposited during stillstands of the shoreline. Fassett (1986) suggested, however, that there is no significant correlation between stacked shoreline deposits and thick coals in the Menefee.

\section{CLIFF HOUSE SANDSTONE}

The Cliff House Sandstone, which overlies the Menefee Formation, is a sandstone and shale sequence in the vicinity of the Reservation (Irwin, 1966). In general, sandstone in the Cliff House is grayish orange to pale yellowish brown, very fine to fine grained, and crossbedded, and it tends to weather to massive cliffs (Irwin, 1966). Sandstone cliffs in the Cliff House are commonly separated by less resistant units that are composed of shaly sandstone and siltstone (Irwin, 1966). Weathering of the less resistant units forms alcoves between the cliffs that are commonly occupied by ancient cliff dwellings in the Mesa Verde area (Wanek, 1959).

The thickness of the Cliff House Sandstone is variable. Maximum thickness in Mesa Verde National Park is about $400 \mathrm{ft}$ (122 m) (Wanek, 1959). In some places in northwestern New Mexico, however, little or no sandstone is present, and marine shale and siltstone of the Lewis Shale lie directly on coal-bearing sediments of the Menefee Formation (Hollenshead and Pritchard, 1961).

The Cliff House Sandstone is a transgressive shallowmarine sandstone that was deposited primarily in the lower to upper shoreface zone of a barrier-island beach front (Siemers and King, 1974). Abundant Ophiomorpha burrows in the Cliff House occur mostly within the shoreface zone. Inoceramus-filled troughs probably represent tidal channels that breached the barrier-island deposits (Siemers and King, 1974).

The Cliff House Sandstone interfingers laterally and vertically with the overlying marine Lewis Shale and with the underlying deltaic deposits of the upper coal member of the Menefee Formation. Wanek (1959) mapped two thick sandstone bodies (the lower tongue and the Barker Dome Tongue) that intertongue with the Menefee Formation in the Mesa Verde area west of the Reservation. These sandstone tongues rise stratigraphically to the southwest and trend in a northwestsoutheast direction. Similar, relatively thick sandstone bodies or benches occur in the subsurface along the same trend southeast of the Mesa Verde area in northwestern New Mexico (fig. 10) (Hollenshead and Pritchard, 1961). The sandstone tongues or benches are similar to those in the Point Lookout, and they were probably deposited during times of relative shoreline stability.

Shaly beds that interfinger with sandstone beds in the Cliff House near the town of Mancos, Colo., northwest of the Reservation wedge out toward the south (Wanek,

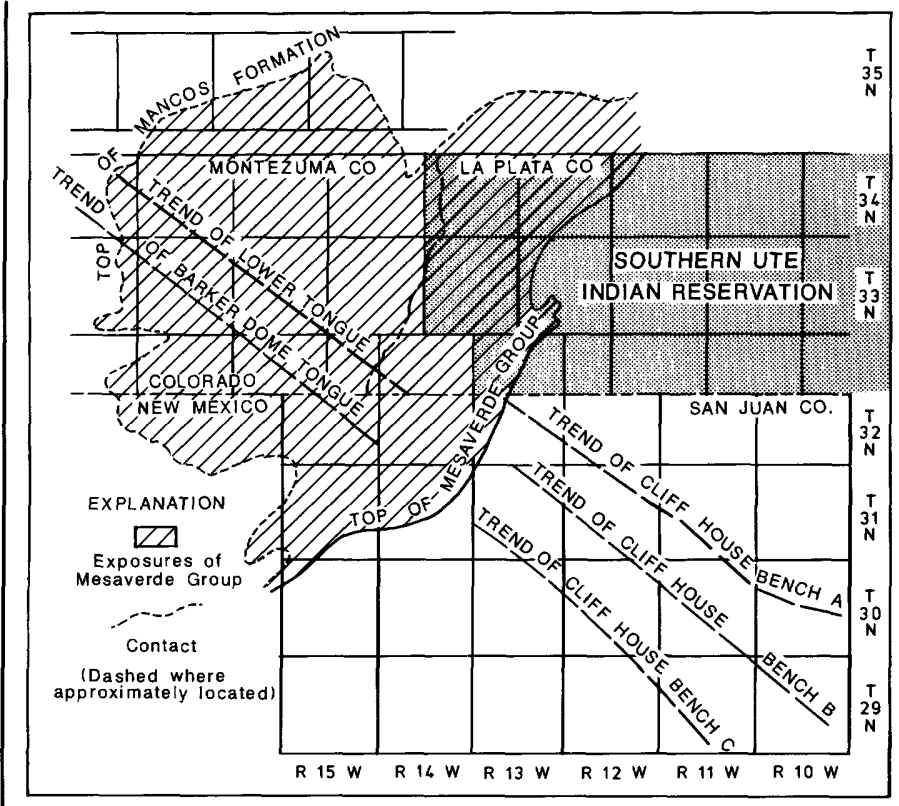

Figure 10. - Map comparing trends of benches in the Cliff House Sandstone in the subsurface in northwestern New Mexico that were mapped by Hollenshead and Pritchard (1961) to trends of benches or tongues of the Cliff House that were mapped in surface exposures in southwestern Colorado by Wanek (1959). Map is from Hollenshead and Pritchard (1961), reprinted by permission of the American Association of Petroleum Geologists.

1959). This relationship suggests that the shaly beds are tongues of offshore shale. The interfingering shale and sandstone beds, which form a bench, were probably deposited during minor transgressions and regressions of the shoreline during a stillstand (Wanek, 1959).

Thick sandstone benches in the Cliff House may occur on the Reservation. Shoreline deposits in the Cliff House generally trend northwest-southeast (fig. 6); the thick shoreline deposits in the Mancos, Colo., area, which were discussed above, project southeastward into the Reservation.

\section{LEWIS SHALE}

The Lewis Shale is a marine shale that was deposited during the T-5 transgression and the R-5 regression (Molenaar, 1983) and is late Campanian in age (Molenaar, 1983). It consists primarily of light- to dark-gray and black shale with interbeds of fine-grained sandstone, limestone, calcareous concretions, and bentonite (Fassett and Hinds, 1971). Bentonite marker beds that give distinctive responses on electric logs include the "Green Marker Horizon" near the base of the Lewis (Hollenshead and Pritchard, 1961) and the Huerfanito Bentonite Bed in the upper part of the Lewis (Fassett and Hinds, 1971). 
The Lewis Shale is wedge shaped with the wedge pointing toward the southwest. In the area of the Reservation, the maximum thickness of the Lewis Shale is about 2,400 $\mathrm{ft}(730 \mathrm{~m})$ (Fassett and Hinds, 1971). The formation is absent, however, a few miles south of the southern boundary of the T-5 transgression (fig. 6). The Lewis is conformable with and grades both laterally and vertically into the underlying Cliff House Sandstone and the overlying Pictured Cliffs Sandstone.

\section{PICTURED CLIFFS SANDSTONE}

The Pictured Cliffs Sandstone was deposited during the final regression ( $R-5)$ of the epeiric Cretaceous sea from the southern Colorado Plateau region during Campanian time (Molenaar, 1983). It is generally divided into an upper part that consists of one or more massive sandstone beds interbedded with some thin shale beds and a lower transitional zone composed of relatively thin intercalations of sandstone and shale (Fassett and Hinds, 1971). On the Reservation, the upper part of the Pictured Cliffs is composed primarily of dark-yellowish-orange and light-gray, medium- to thick-bedded, ledge-forming sandstone (Baltz, 1953). The lower transition zone consists of thin, grayish-orange and light-olive-gray, very fine grained sandstone, interbedded with subordinate amounts of gray shale and siltstone (Baltz, 1953).

The Pictured Cliffs Sandstone contains abundant Ophiomorpha burrows and was deposited primarily in shallow-water, marine shoreface environments (Fassett and Hinds, 1971; Fassett, 1984). Fassett and Hinds (1971) considered Ophiomorpha to be a distinctive lithologic characteristic of the Pictured Cliffs and placed the contact of the Pictured Cliffs with the overlying Fruitland Formation at the top of the highest Ophiomorphabearing sandstone bed.

The Pictured Cliffs rises stratigraphically more than $1,100 \mathrm{ft}(335 \mathrm{~m})$ in $73 \mathrm{mi}(118 \mathrm{~km})$ from the southwestern to the northeastern part of the San Juan basin (Fassett, 1984). Locally stratigraphic rises occur abruptly, and the Pictured Cliffs forms northwest-southeast-trending benches similar to those described by Hollenshead and Pritchard (1961) in the Point Lookout and Cliff House Sandstones in the Mesaverde Group. These benches represent times of relative shoreline stability when sediment supply balanced subsidence and changes in sea level (Fassett and Hinds, 1971). The thickness of the Pictured Cliffs ranges from $285 \mathrm{ft}(87 \mathrm{~m})$ on the western side of the Reservation near the Colorado-New Mexico State line to $215 \mathrm{ft}$ (65 m) near Durango (Baltz, 1953).

Regionally, the Pictured Cliffs is thin or absent in the southeastern part of the basin, and the Fruitland Formation and Kirtland Shale lie directly on the Lewis
Shale near Cuba, N. Mex. (Fassett and Hinds, 1971). Absence of the Pictured Cliffs in this area is probably due either to uplift in the area that caused rapid retreat of the sea, thereby preventing development of shoreline deposits, or to uplift and erosion of shoreline deposits of the Pictured Cliffs prior to Fruitland deposition (Fassett and Hinds, 1971).

\section{FRUITLAND FORMATION}

The Fruitland Formation conformably overlies and interfingers with the Pictured Cliffs Sandstone throughout most of the San Juan basin. The Fruitland consists of interbedded sandstone, siltstone, shale, carbonaceous shale, carbonaceous sandstone and siltstone, coal, and locally, in the lower part, thin limestone composed almost entirely of brackish-water pelecypod shells (Fassett and Hinds, 1971). Sandstone is commonly gray, brown, or olive, fine to medium grained, quartzose, well indurated, and crossbedded. Shale is either dark gray to black and carbonaceous or greenish gray, micaceous, and sandy (Baltz, 1953).

The upper part of the formation consists dominantly of siltstone and shale (Fassett and Hinds, 1971), and sandstone is generally more abundant in the lower part than in the upper. Most of the sandstone and shale beds that make up the Fruitland Formation are discontinuous and interfinger with one another. In outcrop, they commonly pinchout within a few hundred feet. Coal beds, on the other hand, are generally more continuous and locally are traceable for several miles (Fassett and Hinds, 1971).

The Fruitland Formation consists of coastal-swamp, alluvial, and lacustrine deposits that accumulated inland of the prograding and aggrading shoreline deposits of the Pictured Cliffs Formation (Fassett and Hinds, 1971).

The Fruitland is estimated to contain more than 200 billion tons of subbituminous and bituminous coal (Fassett and Hinds, 1971; Fassett, 1986) and is the most important coal-bearing formation in the San Juan basin (Fassett, 1986). The thickest accumulations of coal tend to occur landward of big northwest-southeast-trending stratigraphic rises or benches in the Pictured Cliffs Formation (Fassett and Hinds, 1971). Coal beds in the Fruitland range from thin stringers to beds that are as much as $40 \mathrm{ft}(12 \mathrm{~m})$ thick. The thickest coal deposit in the Fruitland Formation on the Reservation occurs a few miles south of Durango and consists of about $80 \mathrm{ft}(24 \mathrm{~m})$ of thin coal beds separated by numerous thin partings (Zapp, 1949; Fassett and Hinds, 1971). For more detailed information on distribution of coal on the Reservation, see Sandberg (1990). Coal beds in the Fruitland contain considerable amounts of methane gas and are probably the source for gas in nearby sandstones (Rightmire and Choate, 1987). 


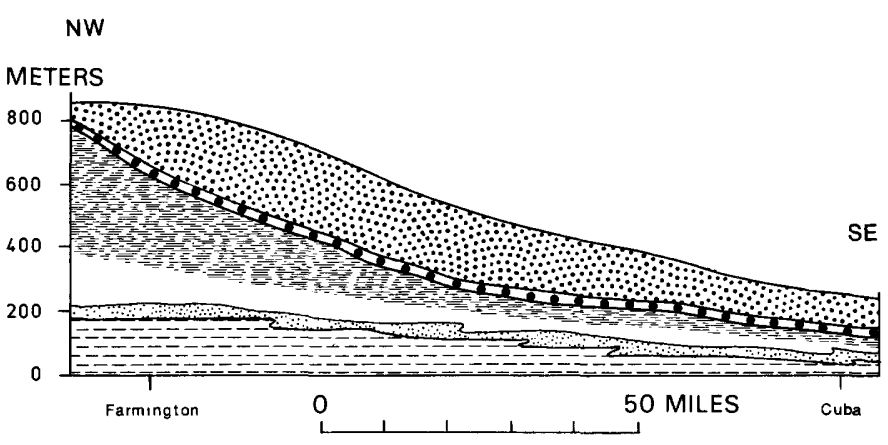

Nacimiento Formation

—-. Ojo Alamo Sandstone

Kirtland Shale

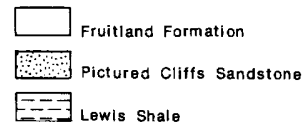

FIGURE 11.-Cross section showing southeastward thinning of the Fruitland-Kirtland interval from the northwestern part of the San Juan basin in the vicinity of the Southern Ute Indian Reservation to the southeastern part of the basin near Cuba, N. Mex. Cross section is from Klute (1986), reprinted by permission of the American Journal of Science.

Regionally the Fruitland Formation thins from the northwestern part of the San Juan basin, where it is as much as $500 \mathrm{ft}(152 \mathrm{~m})$ thick (Baltz, 1953), to the southeastern part, where it is locally absent (fig. 11) (Fassett and Hinds, 1971). The absence of the Fruitland is due either to pre-Ojo Alamo uplift and truncation (Fassett and Hinds, 1971) or to depositional thinning onto a structurally positive area.

\section{KIRTLAND SHALE}

Bauer (1916) divided the Kirtland Shale, which conformably overlies the Fruitland Formation, into a lower shale member, a middle sandstone unit called the Farmington Sandstone Member, and an upper shale member. In the western part of the Reservation, the lower shale member consists of olive- to medium-gray, sandy shale that commonly contains lenses of nonresistant olive-gray, fine-grained sandstone (Baltz, 1953). The lower member also contains thin lenses of carbonaceous shale and abundant amounts of silicified wood at various horizons (Baltz, 1953). Sandstone lithologies in the lower Kirtland and underlying Fruitland are very similar (Baltz, 1953), and the boundary between the two formations is placed above the highest coal bed (Fassett and Hinds, 1971). The Kirtland Shale is probably late Campanian to Maastrichtian in age.

The Farmington Sandstone Member in the western part of the Reservation is a sequence of resistant sandstones that are separated by beds of shale (Baltz, 1953). The sandstone is pale olive, dusky yellow, and grayish orange, fine to medium grained, and crossbed- ded. Shale in the Farmington Sandstone Member is a more pronounced green or olive than is the shale in the lower shale member (Baltz, 1953).

The upper shale member in the western part of the Reservation consists of shale and interbedded lenses of nonresistant, friable sandstone (Baltz, 1953). Shale in the upper member is similar to shale in the lower member. Sandstone is generally light yellowish white and locally conglomeratic. Fassett and Hinds (1971) combined the Farmington Sandstone Member and the upper shale member of Bauer (1916) into one unit because sandstone beds that are indistinguishable from those in the underlying Farmington Sandstone Member locally occupy the stratigraphic position of the upper shale member.

Regionally, the Kirtland Shale thins from the northwestern part of the San Juan basin to the southeastern part (fig. 11) where it is locally absent. Where the Kirtland is locally absent, the lower Tertiary Ojo Alamo Sandstone lies unconformably on the Fruitland Formation. On the western side of the Reservation near the Colorado-New Mexico State line, the Kirtland is about $1,065 \mathrm{ft}(325 \mathrm{~m})$ thick; near Durango it is about $1,200 \mathrm{ft}$ (366 m) thick (Baltz, 1953). Southwest of Durango, the lower shale member is about $325 \mathrm{ft}(99 \mathrm{~m})$ thick, the Farmington Sandstone Member is about $350 \mathrm{ft}(107 \mathrm{~m})$ thick, and the upper shale member is about $450 \mathrm{ft}(137 \mathrm{~m})$ thick (Baltz, 1953).

The Kirtland Shale is an alluvial deposit. Siltstone and mudstone probably represent overbank floodplain deposits, and sandstone probably represents deposition in stream channels (Fassett and Hinds, 1971). The scarcity of coal suggests the scarcity of swamps and the presence of relatively good drainage. The Kirtland Shale was probably deposited by streams on an alluvial plain that lay inland from the Fruitland coastal plain (Fassett and Hinds, 1971). Klute (1986) interpreted fining-upward sandstone beds in the upper part of the Kirtland to represent point bars deposited by meandering streams. Thin crossbedded sandstones were interpreted to be crevasse-splay deposits, and thin coals and carbonaceous siltstones may have been deposited in swamps on the flood plain, in oxbow lakes, or in abandoned chutes on point bars (Klute, 1986).

During most of the Late Cretaceous, shorelines trended northwest-southeast and paleoslopes dipped to the northeast. A change in paleoslope from the northeast to the southwest, however, may have occurred during the deposition of the upper part of the Kirtland Shale (Klute, 1986). Twenty-six crossbed readings from the Farmington Sandstone Member of the Kirtland trend northeastward or eastward, which indicates a northeastdipping paleoslope (Dilworth, 1960). Several hundred crossbeds from the upper shale member, however, dip toward the southwest (Powell, 1972), which indicates 
that the dip of the paleoslope changed to the southwest during deposition of the upper part of the Kirtland (Klute, 1986). In addition a northern source area for the upper shale member is suggested by abundant intermediate volcanic fragments in the upper shale member (Klute, 1986). The only known source of intermediate volcanic material in the region at the end of the Cretaceous was in the area of the San Juan Mountains on the northern perimeter of the basin (Butler and Lindsay, 1985; Klute, 1986).

The change in the dip of the paleoslope during Kirtland deposition is the first major tectonic event of the Laramide orogeny in the San Juan basin. Laramide uplift on the northern and eastern sides of the area of the San Juan basin (see paleoflow directions in Smith and others, 1985 , p. 296, fig. 4) provided source areas for the lower Tertiary rocks described below.

\section{CRETACEOUS-TERTIARY BOUNDARY}

Fossil evidence restricts the Cretaceous-Tertiary boundary to an interval that includes the upper part of the Kirtland Shale and the overlying Ojo Alamo Sandstone (Lindsay and others, 1981; Klute, 1986). Palynological studies indicate that the Cretaceous-Tertiary boundary occurs locally within either the upper part of the Kirtland Shale (Fassett and Hinds, 1971; Newman, 1985 ) or at the Kirtland Shale-Ojo Alamo contact (Newman, 1985). In contrast, dinosaur bones that have been found in the Ojo Alamo suggest that the CretaceousTertiary boundary may occur within the Ojo Alamo (Fassett, 1982).

The nature of the boundary between the Kirtland Shale and the Ojo Alamo Sandstone is also problematical. Some workers placed a major unconformity at the base of the Ojo Alamo (Reeside, 1924; Fassett and Hinds, 1971; Fassett, 1985), whereas others considered the interval to be relatively complete (Dane, 1936; Butler and Lindsay, 1985; Klute, 1986).

Fassett and Hinds (1971) and Fassett (1985) interpreted the southeastward thinning of the FruitlandKirtland interval to be due primarily to uplift and erosion. They suggested that the Fruitland and Kirtland were deposited on a northeast-dipping paleoslope in a nearly uniform thickness over the entire region. Pre-Ojo Alamo tilting of strata to the northwest resulted in erosion of the Fruitland and Kirtland, particularly in the southeastern part of basin. Tertiary continental sediments of the Ojo Alamo Formation were then deposited unconformably on the eroded Cretaceous surface.

Klute (1986) concluded that no unconformity exists between Cretaceous and Tertiary rocks in the San Juan basin because there is local interfingering of the Kirtland
Shale and the Ojo Alamo Sandstone and because paleocurrent data and andesitic volcanic fragments indicate that both the upper part of the Kirtland Shale and the overlying Ojo Alamo Sandstone had similar northern source areas. Klute (1986) suggested that southeastward thinning of the Fruitland-Kirtland interval is due to subsidence in the northern San Juan basin area during deposition. Depositional thinning rather than erosion and truncation is suggested by the fact that magnetopolarity units (intervals of remnant magnetic polarity) in the Fruitland and Kirtland Formations thin from north to south (Butler and Lindsay, 1985).

\section{TERTIARY ROGKS}

\section{OJO ALAMO SANDSTONE}

The Ojo Alamo Sandstone overlies the Kirtland Shale in outcrops in northwestern New Mexico (Baltz and others, 1966) and in the subsurface in the southern part of the Reservation (Fassett, 1985). It is composed of medium- to coarse-grained, crossbedded sandstone and pebbly sandstone that locally contain lenses of claystone and siltstone (Baltz and others, 1966; Klute, 1986). The sandstone consists of lenticular bodies as much as $49 \mathrm{ft}$ $(15 \mathrm{~m})$ thick and more than $0.6 \mathrm{mi}(1 \mathrm{~km})$ long that are separated by thin shaly interbeds and scour surfaces (Klute, 1986). The Ojo Alamo ranges from 20 to $400 \mathrm{ft}$ $(6-120 \mathrm{~m})$ in thickness in the region (Klute, 1986).

The Ojo Alamo Sandstone was deposited by sandy braided streams on a broad alluvial plain (Fassett and Hinds, 1971). Paleocurrent directions are southeast (Klute, 1986; Powell, 1972) or south (Sikkink, 1983), which indicates a northern source. Volcanic fragments in the Ojo Alamo also indicate a northern source in volcanic fields in the San Juan Mountains region (Klute, 1986). Compared to the Kirtland Shale, the Ojo Alamo is enriched in potassium feldspar and polycrystalline quartz (Klute, 1986). Increased amounts of these minerals in the Ojo Alamo probably mark the unroofing of basement rocks by erosion of volcanic cover in the source area (Klute, 1986).

Pebbles in the Ojo Alamo diminish in size from north to south and from west to east (Powell, 1972; Sikkink, 1983). Uplift in the San Juan Mountains area probably provided high-energy streamflow that carried large pebbles and cobbles south to the western side of the San Juan basin. With time, the source area was probably worn down, so that the size of the material carried by the streams became smaller, and the channel system migrated eastward across the basin (Fassett, 1982, 1985). 


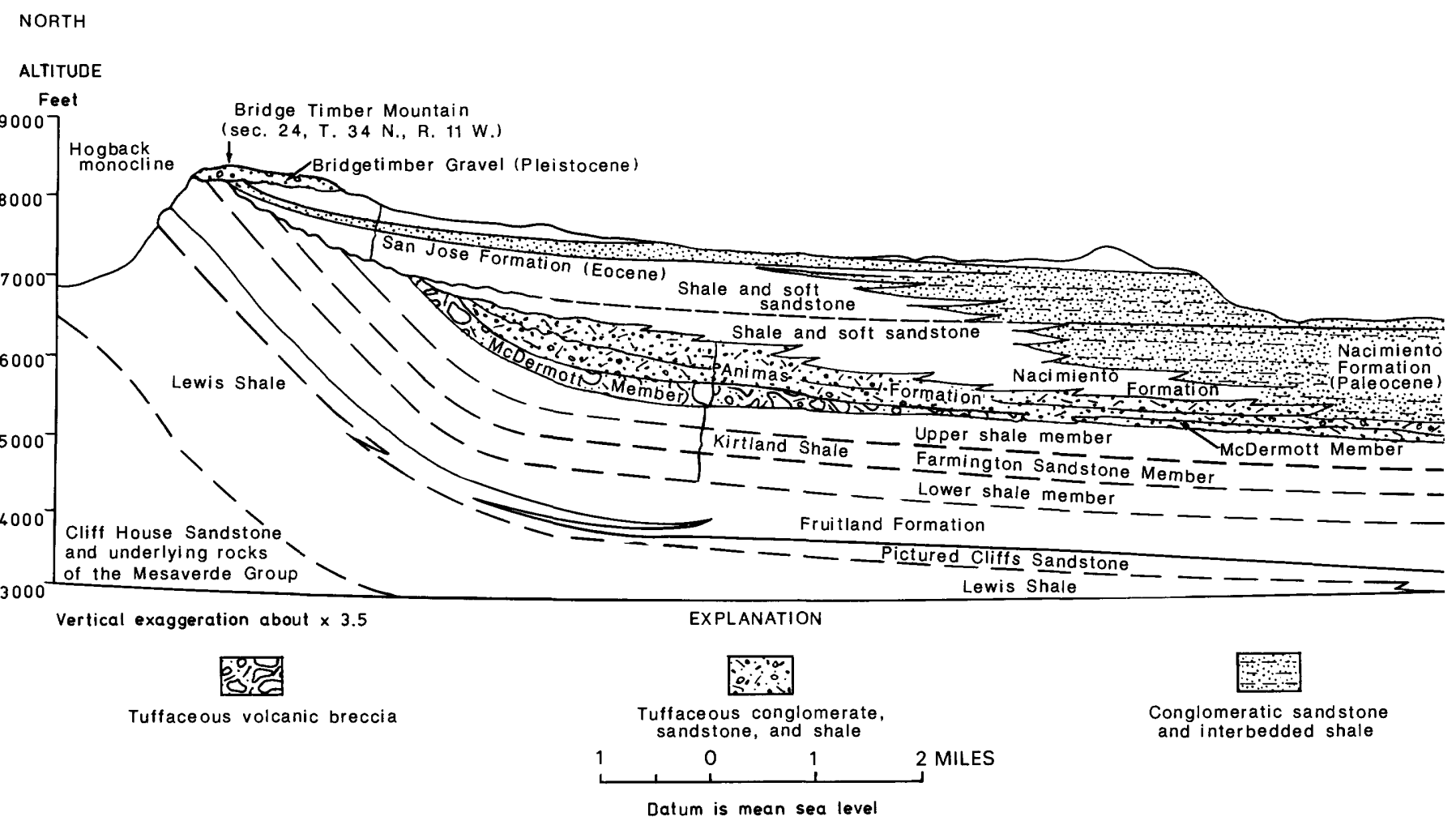

FIGURE 12. -Cross section showing stratigraphic relations of Upper Cretaceous and lower Tertiary rocks in the northwestern part of the San Juan basin in Colorado in the vicinity of the Southern Ute Indian Reservation. Cross section is from Baltz and others (1966).

The base of the Ojo Alamo is generally a scour surface, although locally it is gradational or interfingers with the underlying Kirtland Shale (Klute, 1986). Some workers have placed the Kirtland-Ojo Alamo contact at the base of one of the lenticular sandstones that occur near the top of the Kirtland Shale (Bauer, 1916; Fassett, 1985; Fassett and Hinds, 1971). This contact becomes obscure, however, where the sandstone lens is replaced laterally by shale. Fassett (1985) suggested that this contact is the Cretaceous-Tertiary unconformity which represents a hiatus of several million years.

The Ojo Alamo Sandstone is missing from the northern part of the San Juan basin and is, for the most part, absent from southwestern Colorado. It was probably originally deposited in the northern areas but was later uplifted and eroded (Fassett, 1985).

\section{MCDERMOTT MEMBER OF ANIMAS FORMATION}

The McDermott Member of the Animas Formation locally overlies the Kirtland Shale in the northern San Juan basin (fig. 12). On the Reservation it is composed of very coarse breccia, volcanic conglomerate, coarse tuffaceous sandstone, shale, and thick beds of massive fine- to coarse-grained tuff (Baltz, 1953). The rocks are generally reddish brown to purple and consist of andesitic debris with lesser amounts of quartz, quartzite, and chert. Andesite boulders as large as $4 \mathrm{ft}(1.2 \mathrm{~m})$ in diameter occur locally in the lower beds of McDermott Member, and large cobbles and pebbles of the andesite occur in the upper beds (Baltz, 1953). Fassett (1985) noted that the size of the andesitic boulders decreases south of McDermott Arroyo in the western part of the Reservation and that there are essentially no andesite conglomerates south of the Colorado-New Mexico State line. Basal beds of the McDermott also contain lenses of chert, quartz, and quartzite pebbles that are similar to pebbles in the upper shale member of the Kirtland Shale (Baltz, 1953).

The thickness of the McDermott Member is variable; in general, however, the unit thins to the southeast. Thicknesses in the western part of the Reservation range from as much as $290 \mathrm{ft}(88 \mathrm{~m})$ at one location about $15 \mathrm{mi}$ $(24.2 \mathrm{~km})$ south of Durango to as little as $127 \mathrm{ft}(40 \mathrm{~m})$ near the Colorado-New Mexico State line (Baltz, 1953).

The McDermott Member is probably fluvial in origin (Baltz, 1953), although some conglomeratic layers that coarsen upward may have originated as mudflows (Baars and Ellingson, 1984). The McDermott becomes thinner and less coarse to the southeast which suggests a source to the northwest. Andesitic debris in the McDermott Member may have originated in volcanoes located in the 
region of the present-day La Plata Mountains (Baltz, 1953; Fassett, 1985).

The McDermott Member is probably latest Cretaceous; however, the absence of diagnostic fossils makes its age uncertain. According to Baltz (1953) the McDermott locally intertongues with both the underlying Upper Cretaceous Kirtland Shale and the overlying Paleocene upper part of the Animas Formation. In contrast, Reeside (1924) interpreted the McDermott to be everywhere unconformable with the Animas. He noted that near Durango the McDermott and the upper part of the Animas have an angular relationship. An unconformable relationship in this area was also indicated by Baars and Ellingson (1984) who found highly weathered andesitic debris at the base of the upper part of the Animas that was probably eroded from soils in the upper portions of the McDermott. Mapping by Reeside (1924) and O'Sullivan and Beikman (1963) indicated that the McDermott is unconformably overlain by the Paleocene(?) Ojo Alamo in the Piñon Mesa area in northern New Mexico. The Ojo Alamo in this area is overlain by the Nacimiento Formation which is considered to be laterally equivalent to the upper part of the Animas Formation.

\section{UPPER PART OF ANIMAS FORMATION}

Except in the Piñon Mesa area, the McDermott Member is overlain by the upper part of the Animas Formation. Baltz (1953) reported that the upper part of the Animas in the area of the Reservation is characteristically olive, brown, or various shades of gray. $\mathrm{He}$ divided the formation into a lower conglomeratic sequence and an upper sand and shale sequence. The lower conglomeratic sequence consists of conglomeratic tuff, shale, sandstone, cobble and boulder conglomerate, and locally thin beds of carbonaceous and coaly shale. It is mainly composed of weathered andesite, but there are also considerable amounts of quartz, quartzite, chert, granite, and porphyritic igneous rocks (Baltz, 1953). The upper sand and shale sequence consists of sandy, tuffaceous shale with interbedded tuffaceous coarse-grained sandstone that locally contains granule and pebble conglomerates (Baltz, 1953).

The upper part of the Animas occurs in the northern and northeastern parts of the San Juan basin (fig. 13). According to Reeside (1924, p. 33), it successively overlaps the McDermott Member, the Kirtland Shale, and part of the Fruitland Formation in the region north of Pagosa Junction on the eastern side of the Reservation. Reeside (1924) suggested that the upper part of the Animas is unconformable with all underlying units including the McDermott Member, which he mapped as a separate formation. Fassett (1985) sug- gested that the McDermott Member occurs beneath a regional unconformity that occurs at the boundary between Tertiary and Cretaceous rocks in the San Juan basin. As previously discussed, however, Baltz (1953) interpreted the upper part of the Animas to intertongue with the McDermott Member.

The upper part of the Animas is thought to be Paleocene in age because it grades laterally to the south into the Nacimiento Formation (Dane, 1936), which is Paleocene, and because it contains Torrejonian fossils (Baltz and others, 1966). The upper part of the Animas is $1,200 \mathrm{ft}(335 \mathrm{~m})$ thick at the Animas River near Durango and 2,670 $\mathrm{ft}(814 \mathrm{~m})$ thick near the La Plata-Archuleta County line in Colorado (Reeside, 1924).

Both a southerly decrease in grain size and a probable source for andesite in the La Plata Mountains to the north suggest a northern source area for the upper part of the Animas in the northern San Juan basin; metamorphic and granitic material was probably derived from the northwest in the area of the San Juan and Needle Mountains and from the northeast in the area of the Brazos-Sangre de Cristo uplift (Smith and others, 1985). Intraformational angular unconformities and conglomeratic lithologies within the upper part of the Animas as well as overstepping relations of the upper part of the Animas with underlying units suggest syntectonic deposition by alluvial fans (Smith and others, 1985).

\section{NACIMIENTO FORMATION}

The Nacimiento Formation overlies and interfingers with the upper part of the Animas Formation on the Reservation (figs. 12, 13) (Baltz and others, 1966). To the south in New Mexico, it overlies the Ojo Alamo Sandstone (fig. 13). The Nacimiento is composed of sandstone and shale in the area west of the Animas River on the Reservation (Baltz, 1953). In the northern part of this area, the Nacimiento consists of nonresistant shale and very fine grained sandstone. The shale is generally gray, although locally it is variegated red, white, and gray, especially near the top of the formation. The sandstone is yellow, greenish gray, or tan and quartzose and well sorted (Baltz, 1953). In the southern part of the Animas River area, the Nacimiento consists of a resistant sandstone unit that is composed primarily of crossbedded, quartzose, fine-grained to very coarse grained, locally pebbly sandstone and interbeds of gray, purple, red, and white shale and nonresistant sandstone. Pebbles are commonly potassium feldspar, quartz, quartzite, and chert (Baltz, 1953). Shale in the lower part of the resistant sandstone facies is greenish gray to somber gray and is similar to shale in the uppermost part of the Animas. Shale in the upper part of the resistant sandstone facies is wine red, purple, and gray (Baltz, 


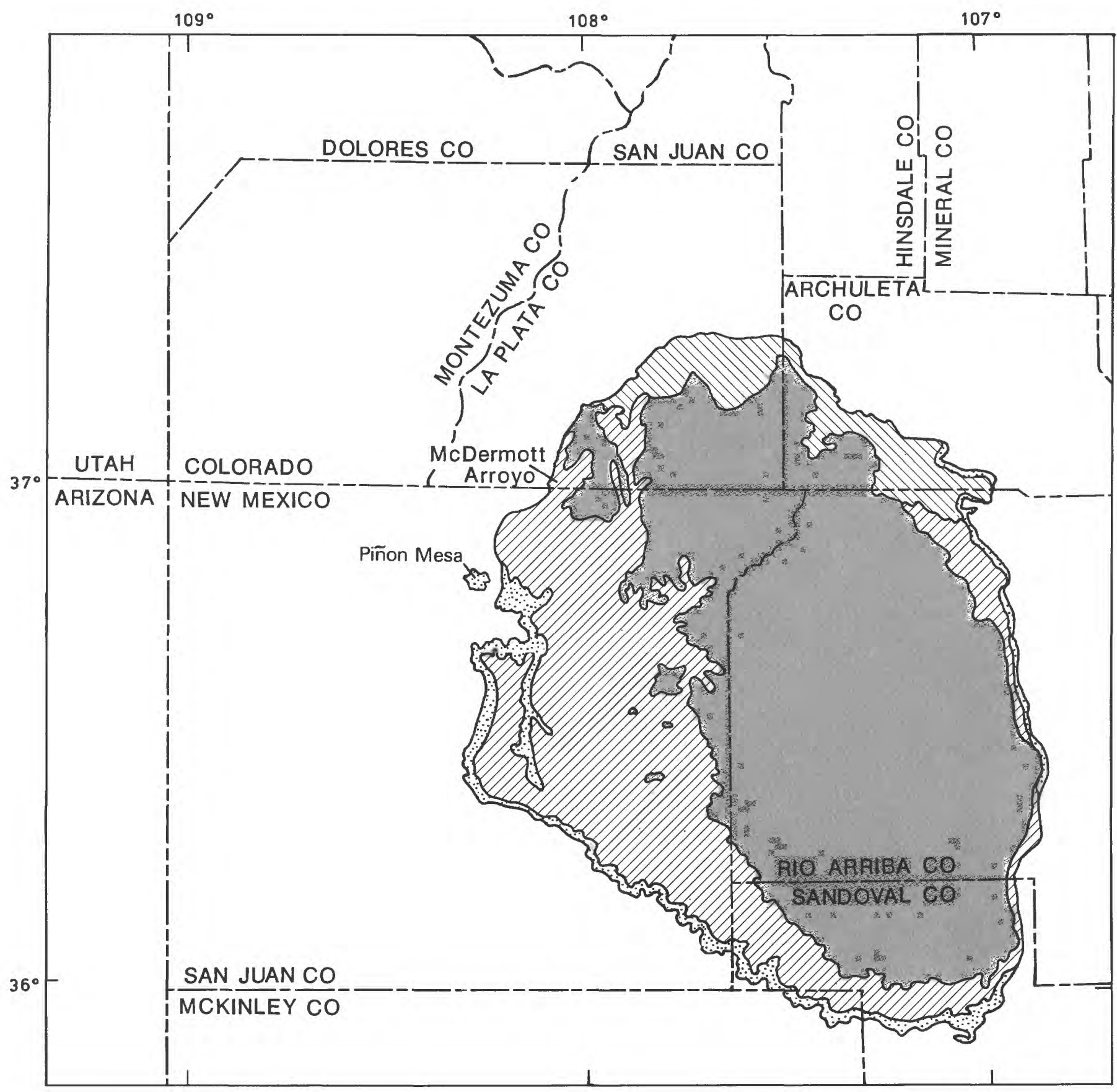

\section{EXPLANATION}
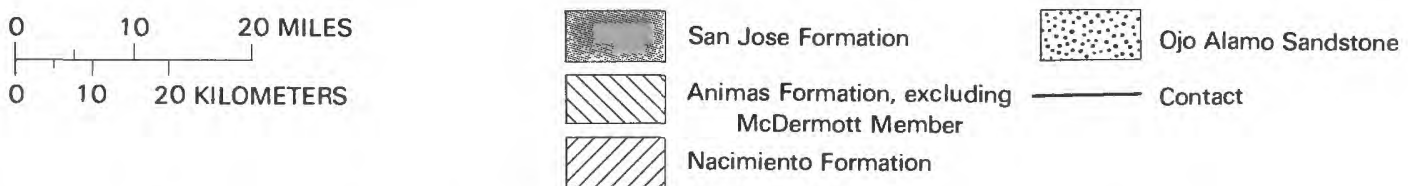

FIGURE 13. - Map showing Tertiary geology of the San Juan basin. Map is from Fassett (1985).

1953). The resistant sandstone grades into nonresistant | into similar shale and nonresistant sandstone to the south shale and very fine grained sandstone to the north and $\mid$ in New Mexico (Baltz, 1953). 
The Nacimiento Formation generally grades laterally into the upper part of the Animas Formation to the north on the northern side of the San Juan basin. Locally, however, upper beds of the Nacimiento overstep steeply dipping beds of the upper part of the Animas Formation (fig. 12) (Baltz and others, 1966). The Nacimiento Formation gradationally overlies the Ojo Alamo Sandstone. The Nacimiento is about $1,450 \mathrm{ft}(442 \mathrm{~m})$ thick near the Colorado-New Mexico State line (Reeside, 1924). It generally thins to the south and is about $800 \mathrm{ft}(240 \mathrm{~m})$ thick in the southeastern part of the San Juan basin (Fassett, 1985).

Torrejonian and Puercan fossils indicate that the Nacimiento Formation is Paleocene in age (Baltz, 1967). The Nacimiento and the upper part of the Animas probably represent the same time interval even though they vary greatly in thickness (Fassett, 1985). The great thickness of the Nacimiento and the upper part of the Animas in the northern part of the basin was probably caused by downwarping-the result of sudden and rapid loading by volcaniclastic material that poured out of the San Juan Mountains eruptive center (Fassett, 1985).

The siltstone, claystone, and sandstone that compose the Nacimiento Formation were deposited in a variety of alluvial subenvironments and include channel, floodplain, alluvial-fan, and lacustrine deposits (Baltz, 1967). Streamflow in Nacimiento time was from the north (Fassett, 1985) and from the east (Baltz, 1967). The Nacimiento is much coarser grained in the northern part of the basin than in the southern part. Streams may have deposited their coarse load in the northern downwarped areas and transported only finer grained material to the southern part of the basin (Fassett, 1985).

Thin silica-rich beds, which are locally interbedded within fine-grained sandstone and mudstone of the Nacimiento Formation in the central portion of the San Juan basin, have been interpreted to be silcretes (Rains, 1981). Silcretes indicate a warm, variably wet climate and poor drainage with a fluctuating water table (Rains, 1981). Fossil remains of fish, crocodiles, turtles, aquatic lizards, various mammals, and temperate flora (Sinclair and Granger, 1914; Gilmore, 1919; Anderson, 1960; Lucas, 1984) also indicate a warm wet climate during Nacimiento deposition (Smith and others, 1985).

\section{SAN JOSE FORMATION}

The San Jose Formation occurs in the northern and eastern portions of the San Juan basin; it overlies the Animas Formation in the northern part of this area and the Nacimiento Formation in the southern part. Baltz (1953) divided the San Jose on the part of the Reservation that is southwest of Durango into a lower shale facies, a sandstone facies, and an upper shale facies. The lower shale facies, which makes up approximately the lower half of the San Jose Formation in the northern part of the area, is composed of variegated white, purple, green, and maroon shale and interbedded, friable, yellow, white, and brown, lenticular, coarsely bedded sandstone, along with a few beds of thin gray silicified tuff (Baltz, 1953). The sandstone facies composes the lower two-thirds of the San Jose Formation in the southern part of the area and overlaps and grades laterally into the lower shale facies to the north (fig. 12) (Baltz, 1953). It is primarily composed of resistant grayish-yellow, fine-grained to granulitic, crossbedded sandstone which contains quartz, jasper, and chert pebbles and thin interbeds of gray, red, and green shale and friable, lenticular sandstone. The upper shale facies overlies the sandstone facies in both the northern and southern parts of the area. The upper shale facies is similar in composition to the lower shale facies, except that shale within the upper facies is predominantly red and purple (Baltz, 1953).

The stratigraphic relationship between the Nacimiento and San Jose Formations in the southeastern part of the basin is better understood than the relation between the Animas and San Jose Formations in the northern part (Lucas and Ingersoll, 1981). Only Eocene fossils have been found in the San Jose Formation in the southern part where the San Jose unconformably overlies the lower to middle Paleocene Nacimiento Formation (Baltz, 1967). A more complete section may occur in the northern part where late Paleocene Tiffanian fauna are present. The Tiffanian strata in the northern part may be equivalent to the time interval represented by the unconformity at the base of the San Jose in the southern part (Baltz, 1967; Lucas and Ingersoll, 1981). Although stratigraphic relations are uncertain and more mapping is needed, the Tiffanian strata in the northern part of the basin are probably part of the Animas Formation (Baltz, 1967).

The San Jose Formation is about $1,000 \mathrm{ft}(305 \mathrm{~m})$ thick a few miles south of Durango, Colo. (Baltz, 1953). Elsewhere in the northern part of the basin it is as much as $2,000 \mathrm{ft}(610 \mathrm{~m})$ thick (Fassett, 1985). The original thickness of the San Jose is not known, however, because complete sections have not been measured on the outcrop and because the basal contact is difficult to pick on geophysical logs (Fassett, 1985).

Uplift and erosion occurred on the northwestern and southeastern rims of the San Juan basin prior to San Jose deposition (Reeside, 1924; Baltz, 1967). On the northwestern rim the San Jose Formation locally lies with sharp angular contact on rocks as old as the Fruitland Formation. On the southeastern rim it rests unconformably on rocks as old as the Lewis Shale. 
Sandstone and conglomeratic sandstone in the San Jose Formation are fluvial in origin (Baltz, 1967; Fassett, 1985; Smith and others, 1985). The formation is generally much sandier in the northern part of the basin than in the southern part, which suggests a northern source area (Fassett, 1985). A preliminary facies analysis and (unpublished) paleocurrent data indicate that sandstone at the base of the San Jose in the east-central part of the basin was deposited on a south- and southwest-sloping alluvial plain (Smith and others, 1985).

\section{TERTIARY IGNEOUS ROCKS}

Dikes, sills, and stocks intrude the sedimentary rocks on the eastern side of the Reservation and surrounding areas (fig. 4) (Wood and others, 1948). An augite andesite sill about $300 \mathrm{ft}(90 \mathrm{~m})$ thick caps Archuleta Mesa in the southeastern corner of the Reservation (Wood and others, 1948). The age of the sill is uncertain, but the sill is younger than the Animas Formation, which it intrudes (Wood and others, 1948).

Dikes are composed of basalt, diabase, and andesite (Wood and others, 1948). They commonly trend N. $10^{\circ} \mathrm{E}$. to $\mathrm{N} .45^{\circ} \mathrm{E}$. and are vertical or nearly vertical (Wood and others, 1948).

\section{SUMMARY}

Except for exposures of the Morrison Formation in a small area in the northeastern corner of the Reservation (fig. 3), all the rocks that crop out on the Southern Ute Indian Reservation are Cretaceous or Tertiary in age. Cretaceous rocks on the Reservation consist of marine, marginal-marine, and coastal-plain deposits. In the later part of the Early Cretaceous, the area of the Reservation lay west of an epeiric sea that was in eastern Colorado. The upper part of the fluvial Burro Canyon Formation was probably deposited in the area of the Reservation at this time. At the end of the Early Cretaceous, sea level in the epeiric sea dropped, which caused streams in the area of the Reservation to degrade; a drainage system was incised into the Burro Canyon Formation. Regression of the Early Cretaceous sea was followed by a transgression that inundated most of the Western Interior including the area of the Reservation. The Upper Cretaceous Dakota Sandstone was deposited during the early stages of this transgression. In southwestern Colorado, the Dakota consists of a basal fluvial unit, which fills the valleys incised into the top of the Burro Canyon Formation, and overlying marginalmarine and deltaic units. The Dakota Sandstone is conformably overlain by the marine Mancos Shale, which was deposited in offshore areas of the epeiric sea.
Variations in lithology in the Mancos reflect fluctuations of the shoreline that occurred southwest of the Reservation. The Mesaverde Group, which overlies the Mancos Shale, was deposited during a transgression and regression of the shoreline in southwestern Colorado. The Mesaverde forms a generally northeasterly prograding deltaic wedge that intertongues with the marine shales of the underlying Mancos Shale and with the overlying Lewis Shale in the area of the Reservation. The marginal-marine rocks of the Pictured Cliffs Sandstone, which overlie and interfinger with the Lewis Shale, were deposited during the final regression of the sea from southwestern Colorado near the end of Late Cretaceous time. The Pictured Cliffs is overlain by the alluvial coastal-plain deposits of the Fruitland Formation and Kirtland Shale.

Shorelines during most of the Late Cretaceous trended northwest-southeast, and coastal plains dipped to the northeast in the area of the Reservation. A change in dip of the paleoslope from the northeast to the southwest occurred during deposition of the Kirtland Shale and represents the first major tectonic event of the Laramide orogeny in southwestern Colorado.

Tertiary sedimentary rocks on the Reservation are mostly fluvial in origin and had northern source areas. These units, which include the Animas, Nacimiento, and San Jose Formations, are the result of episodic uplift along the northern rim of the San Juan basin during the early part of the Laramide orogeny. Numerous Tertiary dikes, sills, and stocks intrude the Tertiary sedimentary rocks on the eastern side of the Reservation and surrounding areas.

\section{REFERENCES GITED}

Anderson, R.Y., 1960, Cretaceous-Tertiary palynology, eastern side of the San Juan basin, New Mexico: New Mexico Bureau of Mines and Mineral Resources Memoir 6, $58 \mathrm{p}$.

Aubrey, W.M., 1986a, The nature of the Dakota-Morrison boundary in the southeastern San Juan basin, in Turner-Peterson, C.E., Santos, E.S., and Fishman, N.S., eds., A basin analysis case study-The Morrison Formation, Grants uranium region, New Mexico: American Association of Petroleum Geologists Studies in Geology, no. 22, p. 93-103.

$1986 \mathrm{~b}$, Tectonics, relative sea level changes and the formation and preservation of the sub-Dakota unconformity in the southeastern Colorado Plateau: Geological Society of America Abstracts with Programs, v. 18, no. 5, p. 339.

1989, Mid-Cretaceous alluvial-plain incision related to eustasy, southeastern Colorado Plateau: Geological Society of America Bulletin, v. 101, p. 443-449.

Baars, D.L., and Ellingson, J.A., 1984, Geology of the western San Juan Mountains, in Brew, D.C., Field Trip Guidebook, 37th Annual Meeting: Geological Society of America, Rocky Mountain Section, p. 1-32.

Baltz, E.H., Jr., 1953, Stratigraphic relationships of Cretaceous and early Tertiary rocks of a part of northwestern San Juan basin: U.S. Geological Survey Open-file Report, $80 \mathrm{p}$. 
1967, Stratigraphy and regional tectonic implications of part of Upper Cretaceous and Tertiary rocks, east-central San Juan basin, New Mexico: U.S. Geological Survey Professional Paper 552, $101 \mathrm{p}$.

Baltz, E.H., Ash, S.R., and Anderson, R.Y., 1966, History of nomenclature and stratigraphy of rocks adjacent to the Cretaceous-Tertiary boundary, western San Juan basin, New Mexico: U.S. Geological Survey Professional Paper 524-D, 23 p.

Barnes, Harley, Baltz, E.H., Jr., and Hayes, P.T., 1954, Geology and fuel resources of the Red Mesa area, La Plata and Montezuma Counties, Colorado: U.S. Geological Survey Oil and Gas Investigations Map OM-149, scale 1:62,500.

Bauer, C.M., 1916, Contributions to geology and paleontology of San Juan County, New Mexico, part 1-Stratigraphy of a part of the Chaco River Valley: U.S. Geological Survey Professional Paper 98-P, p. 271-278.

Beaumont, E.S., Shomaker, J.W., and Kottlowski, F.E., 1971, Stratidynamics of coal deposition in southern Rocky Mountains region, U.S.A. (talk for VII International Kongress für Stratigraphie and Geologie der Carbons, August, 1971), in Shomaker, J.W., Beaumont, E.C., and Kottlowski, R.E., eds., Strippable lowsulfur coal resources of the San Juan basin in New Mexico and Colorado: New Mexico Bureau of Mines and Mineral Resources Memoir 25, p. 175-185.

Bell, T.E., 1986, Deposition and diagenesis in the Brushy Basin Member and upper part of the Westwater Canyon Member of the Morrison Formation, San Juan basin, New Mexico, in TurnerPeterson, C.E., Santos, E.S., and Fishman, N.S., eds., A basin analysis case study-The Morrison Formation, Grants uranium region, New Mexico: American Association of Petroleum Geologists Studies in Geology, no. 22, p. 77-91.

Butler, R.F., and Lindsay, E.H., 1985, Mineralogy of magnetic minerals and revised magnetic polarity stratigraphy of continental sediments, San Juan basin, New Mexico: Journal of Geolagy, v. 93, p. $535-554$.

Campbell, C.V., 1971, Depositional model-Upper Cretaceous Gallup beach shoreline, Shiprock area, New Mexico: Journal Sedimentary Petrology, v. 41 , p. $395-409$.

Carter, W.D., 1957, The disconformity between the Lower and Upper Cretaceous in western Colorado and eastern Utah: Geological Society of America Bulletin, v. 68, p. 307-314.

Cobban, W.A., and Hook, S.C., 1984, Mid-Cretaceous molluscan biostratigraphy and paleogeography of southwestern part of western interior, United States, in Westermann, G.E.G., Jurassic-Cretaceous biochronology and paleogeography of North America: Geological Association of Canada Special Paper 27, p. 257-271.

Dane, C.H., 1936, The La Ventana-Chacra Mesa coal field, part 3, of Geology and fuel resources of the southern part of the San Juan basin, New Mexico: U.S. Geological Survey Bulletin 860-C, p. 81-161.

1960, The boundary between rocks of Carlile and Niobrara age in the San Juan basin, New Mexico and Colorado: American Journal of Science, v. 258-A (Bradley volume), p. 46-56.

Devine, P.E., 1980, Depositional patterns in the Point Lookout Sandstone, northwest San Juan basin, New Mexico: University of Texas at Austin, M.A. thesis, 238 p.

Dilworth, O.L., 1960, Upper Cretaceous Farmington Sandstone of northeastern San Juan County, New Mexico: Albuquerque, University of New Mexico, M.S. thesis, $96 \mathrm{p}$.

Eicher, D.L., 1969, Paleobathymetry of Cretaceous Greenhorn sea in eastern Colorado: American Association of Petroleum Geologists Bulletin, v. 53, p. 2114-2140.
Ekren, E.B., and Houser, F.N., 1959, Relations of Lower Cretaceous and Upper Jurassic rocks, Four Corners area, Colorado: American Association of Petroleum Geologists Bulletin, v. 43, p. 190-201.

1965, Geology and petrology of the Ute Mountain area, Colorado: U.S. Geological Survey Professional Paper 481, 74 p.

Fassett, J.E., 1982, Dinosaurs in the San Juan basin, New Mexico, may have survived the event that resulted in creation of an iridiumenriched zone near the Cretaceous-Tertiary boundary: Geological Society of America Special Paper 190, p. 435-447.

1984, Significance of the rate of deposition of uppermost Upper Cretaceous rocks of the San Juan basin, New Mexico and Colorado: Geological Society of America Abstracts with Programs, v. 16, no. 4, p. 221.

1985, Early Tertiary paleogeography and paleotectonics of the San Juan basin area, New Mexico and Colorado, in Flores, R.M., and Kaplan, S.S., eds., Cenozoic paleogeography of the westcentral United States: Society of Economic Paleontologists and Mineralogists, Rocky Mountain Paleogeography Symposium III, p. 317-334.

1986, The non-transferability of a Cretaceous coal model in the San Juan basin of New Mexico and Colorado, in Fassett, J.E., ed., Geological Society Special Paper 210, p. 155-171.

Fassett, J.E., and Hinds, J.S., 1971, Geology and fuel resources of the Fruitland Formation and Kirtland Shale of the San Juan basin, New Mexico and Colorado: U.S. Geological Survey Professional Paper 676, $76 \mathrm{p}$.

Gilmore, C.W., 1919, Reptilian faunas of the Torrejon, Puerco, and underlying Upper Cretaceous formations of San Juan County, New Mexico: U.S. Geological Survey Professional Paper 119, 71 p.

Hancock, J.M., and Kauffman, E.G., 1979, The great transgressions of the Late Cretaceous: Geological Society of London Journal, v. 136, p. $175-186$.

Hayes, P.T., and Zapp, A.D., 1955, Geology and fuel resources of the Upper Cretaceous rocks of the Barker Dome-Fruitland area, San Juan County, New Mexico: U.S. Geological Survey Oil and Gas Investigations Map OM-144, scale 1:62,500.

Hollenshead, C.T., and Pritchard, R.L., 1961, Geometry of producing Mesa Verde sandstones, San Juan basin, in Peterson, J.A., and Osmond, J.S., eds., Geometry of sandstone bodies: American Association of Petroleum Geologists, p. 98-118.

Hook, S.C., Cobban, W.A., and Landis, E.R., 1980, Extension of intertongued Dakota Sandstone-Mancos Shale terminology into the Zuni basin: New Mexico Geology, v. 2, no. 3. p. 42-46.

Huffman, A.C., Jr., 1987, Petroleum geology and hydrocarbon plays of the San Juan Basin petroleum province: U.S. Geological Survey Open-File Report 87-450-B, 67 p.

Irwin, F.H., 1966, Geology and availability of ground water on the Ute Mountain Indian Reservation, Colorado and New Mexico, U.S. Geological Survey Water-Supply Paper 1576-G, 109 p.

Kirk, A.R., Huffman, A.C., Jr., and Zech, R.S., 1988, Subsurface correlation of Jurassic and Cretaceous rocks having occurrences of uranium, coal, and oil; Mariano Lake-Lake Valley drilling project, northwestern New Mexico: U.S. Geological Survey Oil and Gas Investigations Chart OC-130.

Klute, M.A., 1986, Sedimentology and sandstone petrography of the Upper Kirtland Shale and Ojo Alamo Sandstone, CretaceousTertiary boundary, western and southern San Juan basin, New Mexico: American Journal of Science, v. 286, p. 463-488.

Lamb, G.M., 1968, Stratigraphy of the Lower Mancos Shale in the San Juan basin: Geological Society of America Bulletin, v. 79, p. $827-854$.

1973, The Lower Mancos Shale in the northern San Juan basin, in Fassett, J.E., ed., Cretaceous and Tertiary rocks of the southern Colorado Plateau: Four Corners Geological Society Memoir, p. 72-77. 
Landis, E.R., Dane, C.H., and Cobban, W.A., 1973, Stratigraphic terminology of the Dakota Sandstone and Mancos Shale, westcentral New Mexico: U.S. Geological Survey Bulletin 1372-J, 44 p.

Lindsay, E.H., Butler, R.F., and Johnson, N.M., 1981, Magnetic polarity of Late Cretaceous and Paleocene continental deposits, San Juan basin, New Mexico: American Journal Science, v. 281, p. $390-434$.

Lucas, S.G., 1984, Puercan (early Paleocene) biostratigraphy, Nacimiento Formation, San Juan basin, New Mexico: Geological Society of America Abstracts with Programs, v. 16, p. 245.

Lucas, S.G., and Ingersoll, R.V., 1981, Cenozoic continental deposits of New Mexico, an overview: Geological Society of America Bulletin, pt. I, v. 92, p. 917-932.

Maxwell, C.H., 1976, Stratigraphy and structure of the Acoma region, New Mexico, in Woodward, L.A., and Northrop, S.A., eds., Tectonics and mineral resources of southwestern North America: New Mexico Geological Society Special Publication 6, p. 95-101.

McCubbin, D.G., 1969, Cretaceous strike-valley sandstone, northwestern New Mexico: American Association of Petroleum Geologists Bulletin, v. 53, p. 2114-2140.

Molenaar, C.M., 1983, Major depositional cycles and regional correlations of Upper Cretaceous rocks, southern Colorado Plateau and adjacent areas, in Reynolds, M.W., and Dolly, E.D., Mesozoic paleogeography of the west-central United States, Rocky Mountain Paleogeography Symposium II: Society of Economic Paleontologists and Mineralogists Rocky Mountain Section, p. 201-224.

1991, Stratigraphic cross sections of Upper Cretaceous rocks in the northern San Juan Basin, Southern Ute Indian Reservation, southwestern Colorado: U.S. Geological Survey Professional Paper 1505-C, $12 \mathrm{p}$.

Newman, K.R., 1985, Stratigraphic implications of palynomorphs from Kirtland and Ojo Alamo Formations (Cretaceous and Paleocene), San Juan basin, New Mexico: Geological Society of America Abstracts with Programs, v. 17., p. 258.

Nummedal, D., Swift, D.J.P., and Wright, R., 1986, Depositional sequences and shelf sandstones in Cretaceous strata of the San Juan basin, New Mexico-A field guide for the Seventh Annual Research Conference: Society of Economic Paleontologists and Mineralolgists Foundation, Gulf Coast Section, $281 \mathrm{p}$.

O'Sullivan, R.B., and Beikman, H.M., 1963, Geology, structure, and uranium deposits of the Shiprock quadrangle, New Mexico and Arizona: U.S. Geological Survey Miscellaneous Geological Investigations Map I-345, scale 1:250,000, 2 sheets.

Owen, D.E., 1973, Depositional history of the Dakota Sandstone, San Juan basin area, New Mexico, in Fassett, J.E., ed., Cretaceous and Tertiary rocks of the southern Colorado Plateau: Four Corners Geological Society Memoir, p. 37-51.

Peterson, Fred, and Kirk, A.R., 1977, Correlation of the Cretaceous rocks in the San Juan, Black Mesa, Kaiparowits and Henry Basins, southern Colorado Plateau, in New Mexico Geological Society Guidebook, 28th Field Conference, San Juan Basin III: p. 167-178.

Pitman, W.C., 1978, Relationship between sea level change and stratigraphic sequences: Geological Society of America Bulletin, v. 89 , p. $1289-1403$.

Powell, J.S., 1972, The Gallegos Sandstone (formerly Ojo Alamo Sandstone) of the San Juan basin, New Mexico: Tucson, University of Arizona, M.S. thesis, $131 \mathrm{p}$.

Pratt, W.P., and Henkes, W.C., 1976, Status of mineral resource information for the Southern Ute Indian Reservation, Colorado, Administrative Report BIA-19: prepared by the U.S. Geological Survey and U.S. Bureau of Mines for the U.S. Bureau of Indian Affairs, $36 \mathrm{p}$.

Rains, P.E., 1981, Paleocene silcrete beds in the San Juan basin: University of Arizona, M.S. thesis, 81 p.
Rankin, C.H., 1944, Stratigraphy of the Colorado Group, Upper Cretaceous in northern New Mexico: New Mexico Bureau of Mines and Mineral Resources Bulletin 20, p. 1-26.

Reeside, J.B., Jr., 1924, Upper Cretaceous and Tertiary formations of the western part of the San Juan basin, Colorado and New Mexico: U.S. Geological Survey Professional Paper 134, p. 1-70.

Rightmire, C.T., and Choate, R., 1987, Coal-bed methane and tight gas sands interrelationships, in Spencer, C.W., and Mast, R.F., eds., Geology of tight gas reservoirs: American Association of Petroleum Geologists Studies in Geology, no. 24, p. 87-110.

Sageman, B.B., 1985, High-resolution stratigraphy and paleobiology of the Hartland Shale Member, in Kauffman, E.G., Pratt, L.M., and Zelt, F.B., Fine-grained deposits and biofacies of the Cretaceous western interior-Evidence of cyclic sedimentary processes: Society of Economic Paleontologists and Mineralogists Midyear Meeting, Field Trip Guidebook 4, p. 110-121.

Sandberg, D.T., 1990, Coal resources of Upper Cretaceous Fruitland Formation in the Southern Ute Indian Reservation, southwestern Colorado: U.S. Geological Survey Professional Paper 1505-D, $24 \mathrm{p}$.

Sheitiwy, M.M., 1978, Sedimentologic and stratigraphic analysis of the Point Lookout Sandstone, southeast San Juan basin, New Mexico: Socorro, New Mexico Institute of Mining and Technology, Ph. D. dissertation, $262 \mathrm{p}$.

Siemers, C.T., and King, N.R., 1974, Macroinvertebrate paleoecology of a transgressive marine sandstone, Cliff House Sandstone (Upper Cretaceous), Chaco Canyon, northwestern New Mexico, in Siemers, C.T., Woodward, L.A., and Callender, J.F., eds., New Mexico Geological Society Guidebook, 25th Field Conference, Ghost Ranch (Central-Northern New Mexico): p. 267-277.

Siemers, C.T., and Wadell, J.S., 1977, Humate deposits of the Menefee Formation (Upper Cretaceous), northwestern New Mexico, in Fassett, J.E., Supplement New Mexico Geological Society Guidebook, 28th Field Conference, San Juan Basin III: p. 1-22.

Sikkink, P.G.L., 1983, Depositional environment of the Tertiary Ojo Alamo Sandstone, San Juan basin, New Mexico: Geological Society of America Abstracts with Programs, v. 15, p. 308.

Sinclair, W.J., and Granger, Walter, 1914, Paleocene deposits of the San Juan basin, New Mexico: American Museum of Natural History Bulletin, v. 33, p. 297-316.

Smith, L.N., Lucas, S.G., and Elston, W.E., 1985, Paleogene Stratigraphy, sedimentation and volcanism of New Mexico, in Flores, R.M., and Kaplan, S.S., eds., Cenozoic paleogeography of westcentral United States, Rocky Mountain Paleogeography Symposium III: Society of Economic Paleontologists and Mineralogists, Rocky Mountain Section, 293-315.

Tschudy, R.H., Tschudy, B.D., and Craig, L.C., 1984, Palynological Evaluation of Cedar Mountain and Burro Canyon Formations, Colorado Plateau: U.S. Geological Survey Professional Paper 1281, $21 \mathrm{p}$.

Turner-Peterson, C.E., Fishman, N.S., and Hay, R.L., 1986, Recognition of an extensive Jurassic playa-lake complex-The Brushy Basin Member of the Morrison Formation, Colorado Plateau: Abstracts, Society of Economic Petroleum Geologists Annual Midyear Meeting, v. III, p. 37.

Tweto, Ogden, 1979, Geologic map of Colorado: U.S. Geological Survey Map, scale 1:500,000.

Vail, P.R., Mitchum, R.M., Jr., Todd, R.G., Widmier, J.M., Thompson, S., III, Sangree, J.B., Bubb, J.N., and Gatelid, W.G., 1977, Seismic stratigraphy and global changes of sea level, in Payton, C.E., ed., Seismic stratigraphy-Applications to hydrocarbon exploration: American Society of Petroleum Geologists Memoir 26, p. 49-212. 
Wanek, A.A., 1959, Geology and fuel resources of the Mesa Verde area, Montezuma and La Plata Counties, Colorado: U.S. Geological Survey Bulletin 1072-M, p. 667-721.

Whyte, M.R., and Shomaker, J.W., 1977, A geological appraisal of the deep coals of the Menefee Formation of the San Juan basin, New Mexico, in Fassett, J.E., Supplement to New Mexico Geological Society Guidebook, 28th Field Conference, San Juan Basin III: p. $41-48$.

Wood, G.H., Kelley, V.C., and MacAlpin, A.J., 1948, Geology of southern part of Archuleto County, Colorado: U.S. Geological
Survey Oil and Gas Investigations Preliminary Map 81, scale $1: 63,360$.

Wright, Robyn, 1986, Cycle stratigraphy as a paleogeographic toolPoint Lookout Sandstone, southeastern San Juan basin, New Mexico: Geological Society of America Bulletin, v. 96, p. 661-673.

Zapp, A.D., 1949, Geology and coal resources of the Durango area, La Plata and Montezuma Counties, Colorado: U.S. Geological Survey Oil and Gas Investigations Preliminary Map 109, scale 1:31,680.

Zech, R.S., 1982, Paleoshorelines in the Upper Cretaceous Point Lookout Sandstone, southern San Juan basin, New Mexico: U.S. Geological Survey Open-File Report 82-135, 23 p. 


\section{Stratigraphic Cross Sections of Upper Cretaceous Rocks in the Northern San Juan Basin, Southern Ute Indian Reservation, Southwestern Colorado}

By C.M. MOLENAAR and J.K. BAIRD

GEOLOGY AND MINERAL RESOURCES OF THE SOUTHERN UTE INDIAN RESERVATION

Edited by ROBERT S. ZECH

U.S. GEOLOGICAL SURVEY PROFESSIONAL PAPER 1505-C

Prepared in cooperation with the Southern Ute Tribe and the U.S. Bureau of Indian Affairs

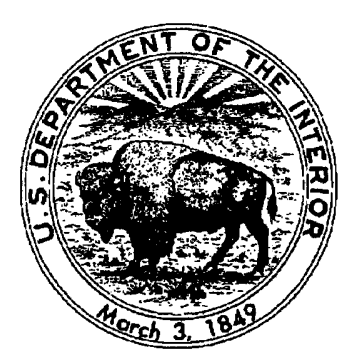

UNITED STATES GOVERNMENT PRINTING OFFICE, WASHINGTON : 1991 



\section{CONTENTS}

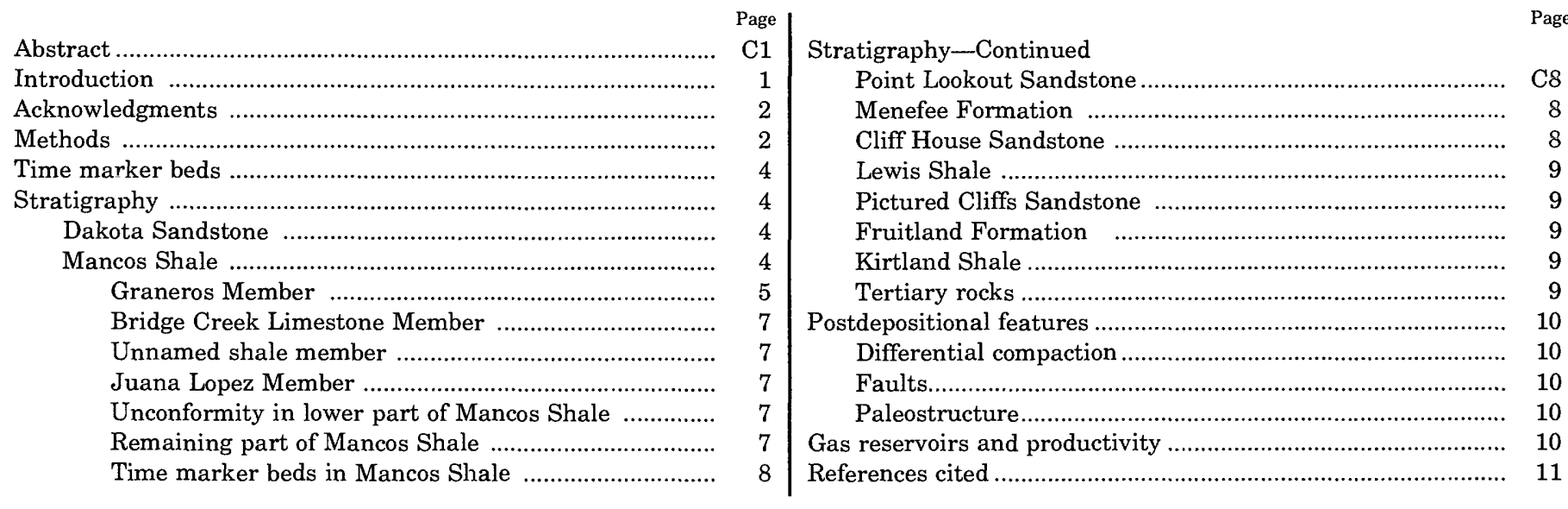

\section{ILLUSTRATIONS}

[Plates are in pocket]

Plate 1. North-south stratigraphic cross section $A-A^{\prime}$ of Upper Cretaceous rocks, northern San Juan Basin, southwestern Colorado.

2. North-south stratigraphic cross sections $B-B^{\prime}$ and $C-C^{\prime}$ of Upper Cretaceous rocks, northern San Juan Basin, southwestern Colorado.

3. East-west stratigraphic cross sections $D-D^{\prime}$ and $E-E^{\prime}$ of Upper Cretaceous rocks, northern San Juan Basin, southwestern Colorado.

Page

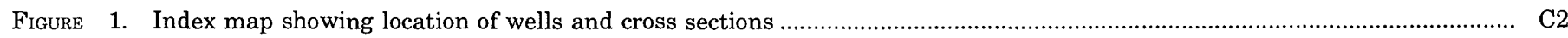

2. Stratigraphic cross section showing Upper Cretaceous rocks across the San Juan Basin, New Mexico and Colorado .......... 5

3. Chronostratigraphic cross section of Upper Cretaceous rocks from the Zuni basin to the northern San Juan Basin ........... 6

\section{TABLE}





\title{
STRATIGRAPHIC CROSS SECTIONS OF UPPER CRETACEOUS ROCKS IN THE NORTHERN SAN JUAN BASIN, SOUTHERN UTE INDIAN RESERVATION, SOUTHWESTERN COLORADO
}

\author{
By C.M. MolenaAr and J.K. BAird
}

\begin{abstract}
The northern part of the San Juan Basin, once part of the larger Western Interior basin, is an early Tertiary structural depression in which a thick section of Cretaceous rocks is preserved. The large number of drill holes and the relatively simple structure make this area ideal for stratigraphic analyses through the use of stratigraphic cross sections.

Upper Cretaceous rocks of the northern part of the basin, which are as much as 6,500 feet (1,980 meters) thick, comprise a classic sequence of intertonguing marine and nonmarine facies. Many of the major sandstone units and the coal beds are gas-producing reservoirs. Geophysical logs from closely spaced drill holes throughout most of the area provide data for detailed rock unit correlations which can be made by using numerous time marker beds within the marine shale sections. These marker beds provide a time framework for construction of cross sections that show (1) continuity or discontinuity of lithologic units, (2) diachroneity and stratigraphic rising of coastal sandstone bodies associated with the two major transgressions and regressions of the Western Interior seaway within this area, (3) cut-out section due to faulting, (4) low-amplitude paleostructural features, and (5) low-relief differential compaction features associated with lateral heterogeneities in sand-shale sections.
\end{abstract}

\section{INTRODUCTION}

Five stratigraphic cross sections across the Southern Ute Indian Reservation in the northern part of the San Juan Basin are shown in this report. These sections

Manuscript approved for publication, October 31, 1990. utilize well-log data to illustrate physical relations of Upper Cretaceous rocks across the deep (northern) part of this gas-producing basin (fig. 1). The sections are located inside the steep flanking monoclines in the deep, low-dipping part of the basin where drilled thicknesses in all but one well are essentially true thicknesses. Table 1 lists the wells shown on the cross sections. These cross sections were previously published as U.S. Geological Survey Miscellaneous Field Studies Map MF-2068 (Molenaar and Baird, 1989).

On the basis of detailed correlations of closely spaced borehole geophysical logs (generally $2-4 \mathrm{mi}$ or $4-6 \mathrm{~km}$ apart), numerous time marker beds or time lines were established within the offshore marine section. These time marker beds provide reference surfaces of deposition from which several depositional features can be documented. Depositional features, such as (1) continuity or discontinuity of lithologic units, (2) lateral facies relations, and (3) diachroneity and stratigraphic rising of coastal sandstone units, can be recognized. In addition, postdepositional features, such as (1) low-relief differential compaction, (2) cut out of section by faulting, and (3) paleostructure, can be identified. Because of the discontinuous nature of nonmarine deposition, detailed correlation of beds was not attempted in the nonmarine section although correlations over limited areas within the coal-bearing sections may be possible on larger scale cross sections. 


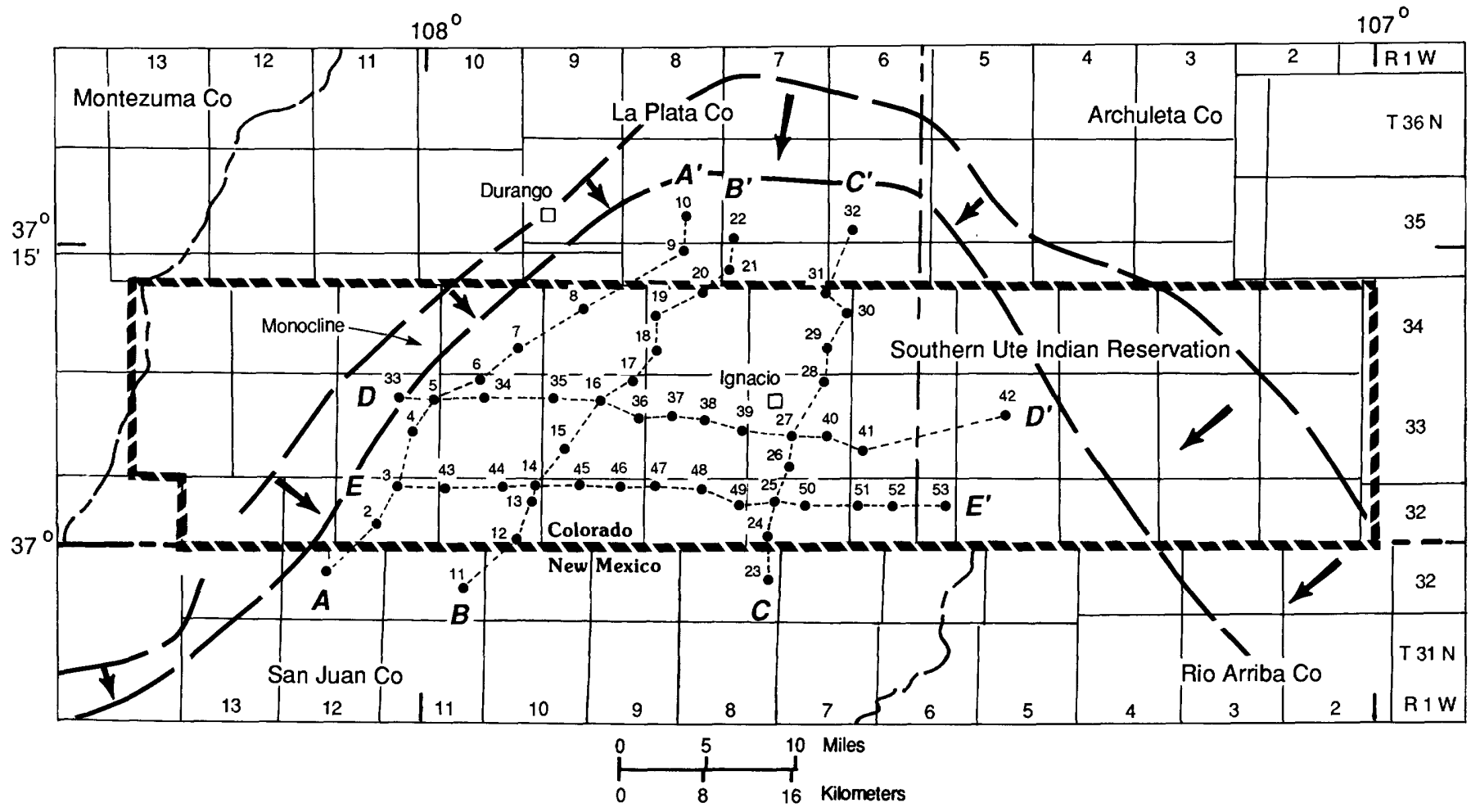

Figure 1.-Index map showing location of wells (dots) and cross sections (dashed lines) in respect to steeply dipping monocline (long dashed lines; arrows indicate dip).

The datum for all sections is the Huerfanito Bentonite Bed of the Lewis Shale, a prominent marker bed in the upper part of the Lewis Shale. This bed, which is the result of a volcanic ash fall, is believed to have been deposited on a nearly flat floor in this part of the basin.

In addition to the correlations shown, initial gas production rates and producing intervals are shown for wells on the cross sections.

\section{ACKNOWLEDGMENTS}

This work was done for the Division of Energy and Mineral Resources of the U.S. Bureau of Indian Affairs under the direction of Steve Manydeeds in cooperation with the Southern Ute Indian Tribe. Appreciation for assistance in planning the study is extended to Brad Boyce of the Southern Ute Tribal Energy Office and Clarence Harr, consulting geologist for the Tribe. Curt Huffman and Jim Fassett reviewed the cross sections and manuscript.

\section{METHODS}

The borehole logs used in these cross sections were digitized by hand-tracing the spontaneous potential (SP) or gamma-ray logs and the conductivity logs. If conductivity logs were not available, the resistivity logs were used. If neither conductivity nor resistivity logs were available, other logs, such as neutron logs in wells 15 and 35 and a transit-time log in well 42 , were used. The original logs were at a scale of $1 \mathrm{in} .=50 \mathrm{ft}(1 \mathrm{~cm}=$ $6 \mathrm{~m}$ ); the logs were replotted at a scale of $1 \mathrm{in} .=200 \mathrm{ft}$ $(1 \mathrm{~cm}=24 \mathrm{~m})$, and the amplitude of the logs was adjusted to a scale of lesser magnitude to fit the cross sections better. In addition, the conductivity logs were converted to a resistivity scale. Most of the correlations were made by using the original conductivity logs with the wide amplitude range; however, because the amplitude was attenuated on the replotted logs, the basis for many of the correlations is less obvious on the cross sections. In a few places, well logs between the control wells shown on the cross sections were used to corroborate the correlations. Correlations of marker beds on each cross section were made separately, and the correlated marker beds are not necessarily the same on all sections. In general, the marker beds shown are those that could be correlated the farthest on each cross section and attempts were made to show a marker bed at least every 100-200 vertical $\mathrm{ft}$ (30-60 $\mathrm{m})$, although many more could have been shown. The marker beds shown may not be the most prominent correlatable beds in a particular area or part of the 
TABLE 1.-List of wells used on cross sections of Upper Cretaceous rocks in the northern San Juan Basin, southwestern Colorado

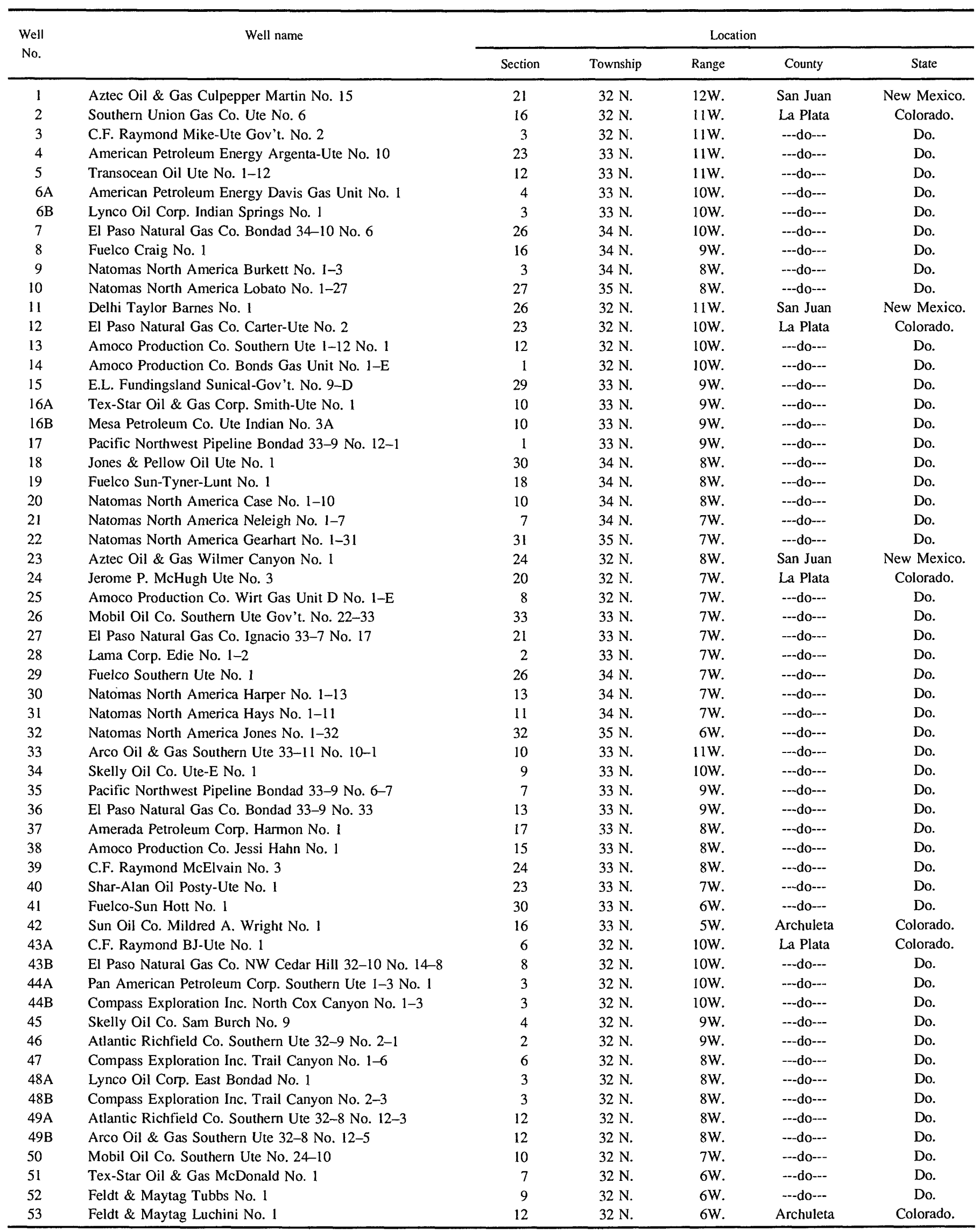


section. The final cross sections were reduced to the present size (vertical scale of $1 \mathrm{in} .=300 \mathrm{ft}$ or $1 \mathrm{~cm}=36$ $\mathrm{m}$ ) for convenience in handling them.

\section{TIME MARKER BEDS}

The many time marker beds are based mostly on conductivity or resistivity patterns in the marine shale section; these patterns reflect a variety of obvious to subtle lithologic changes within the thick shale sections, such as discrete bentonite beds, bentonitic zones, silty or sandy zones, and variations in calcium carbonate content. Some of the well-log markers are reflected as solitary conductivity spikes, but most are conductivity patterns over intervals of as much as 100 $\mathrm{ft}(30 \mathrm{~m})$ that can be recognized from well to well. Although some spikes on gamma-ray logs can be correlated, many seem to be random and cannot be correlated; however, an overall pattern of variations in gamma-ray deflections over several tens of feet is useful for correlating. The SP curves differentiate sandstone and shale in the upper part of the stratigraphic section. In the lower, deeper part of the basin, the SP response is greatly attenuated, and in most cases this log has been replaced by the gammaray $\log$ on the cross sections.

\section{STRATIGRAPHY}

Figure 2 shows the regional stratigraphic relations of Upper Cretaceous rocks across the entire San Juan Basin. Figure 3 is a chronostratigraphic section showing age relations across the basin. In figure 3 , approximated time, rather than thickness, is represented on the vertical scale; thus, thickness can be indicated only by notation. The following is a brief description of the rock units, in ascending order, in the Southern Ute Indian Reservation (northern part of the San Juan Basin) with comments relating to depositional features shown on the five accompanying cross sections and to the contacts as interpreted from the geophysical logs. For a more detailed description, see Aubrey in Chapter B of this volume.

\section{DAKOTA SANDSTONE}

The Dakota Sandstone consists of sandstone, shale, and minor amounts of conglomerate and coal; the sediments of all these rocks were deposited along and landward from the advancing Western Interior sea.
The major part of the Dakota is fluvial in origin, but the upper part consists of paludal and back-barrier facies that grade upward into the overlying Mancos Shale. In some places the two formations intertongue. The log character of the nonmarine part of the Dakota is variable because of the discontinuous or lenticular distribution patterns of lithologic units within this facies. The log character of the marine sandstones at the top of the Dakota, especially the tongues within the overlying marine shale, shows more continuity on the cross sections than does that of the nonmarine part.

Most wells did not penetrate, or the logs did not extend to, the base of the Dakota. A few wells penetrated the upper part of the Upper Jurassic Morrison Formation, which consists mostly of variegated nonmarine shale. The lower part of the interval shown as Dakota on the cross sections may include the Lower Cretaceous Burro Canyon Formation. Harr (1988) considered much of the lower half of the main interval that is here shown as Dakota to be Burro Canyon Formation. Separation of these two formations can be made in outcrops but is difficult on well logs. The upper contact of the Dakota is usually placed at the top of the highest sandstone. Locally this is a discontinuous offshore shelf sandstone; hence the contact shifts abruptly in some places. The Twowells and Paguate Tongues of the Dakota are discontinuous shelf sandstone units that were correlated into the northern San Juan Basin from the southern margins of the basin (fig. 2), where they were named; some workers informally refer to these tongues in the subsurface as "Graneros sands." Harr (1988) and Bowman (1978a) used the name Dakota " $A$ " for what we show as Paguate or the section equivalent to the Paguate.

\section{MANCOS SHALE}

The Mancos Shale is a thick, dominantly shale formation that is composed of sediments deposited offshore as the Cretaceous seaway first transgressed and then regressed across the entire San Juan Basin. The shale is generally dark gray, silty in parts, calcareous in variable amounts, and locally bentonitic. Thin beds of bentonite are common in most parts of the Mancos. In this part of the San Juan Basin, three formally named members are recognized in the lower part of the Mancos Shale: the Graneros, Bridge Creek Limestone, and Juana Lopez Members. An informal, unnamed shale member is present between the Bridge Creek Limestone and Juana Lopez Members. The remaining major part of the Mancos overlies the Juana Lopez Member. 
SSW

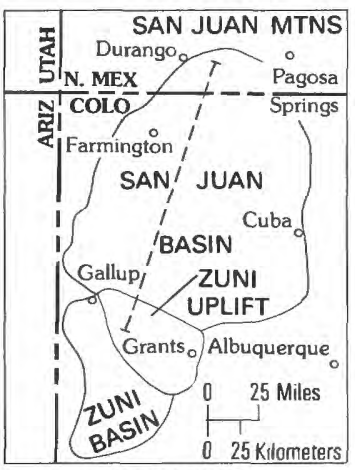

INDEX MAP

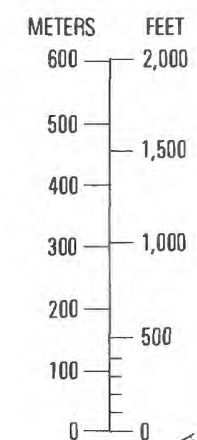

VERT. EXAG. $=84$

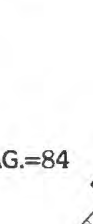

\section{.}


SSW 200 MILES (320 KILOMETERS)

ZUNI BASIN

\section{SAN JUAN BASIN}

\section{EXPLANATION}

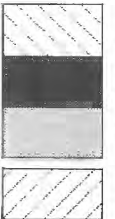

Nonmarine rocks

Marine and coastal sandstone

Marine shale, siltstone, and minor amounts of sandstone and limestone Hiatus or section removed by erosion

Kcht Sandstone exposed at Tsaya Canyon

Kph

Hosta Tongue of Point Lookout Ss

Kcda Dalton Ss Mbr of Crevasse Canyon Fm

Kcbp Borrego Pass Sandstone Lentil of Crevasse Canyon Formation

Kth Tres Hermanos Formation

Kthfr Fite Ranch Mbr of Tres Hermanos Fm

Kthc Carthage Mbr of Tres Hermanos Fm

Ktha Atarque Ss Mbr of Tres Hermanos Fm

$\mathrm{Ka} \quad$ Atarque Sandstone


$\dot{\mathrm{O}} \frac{\mathrm{U}}{\mathrm{M}}$

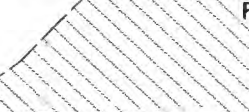

Formation
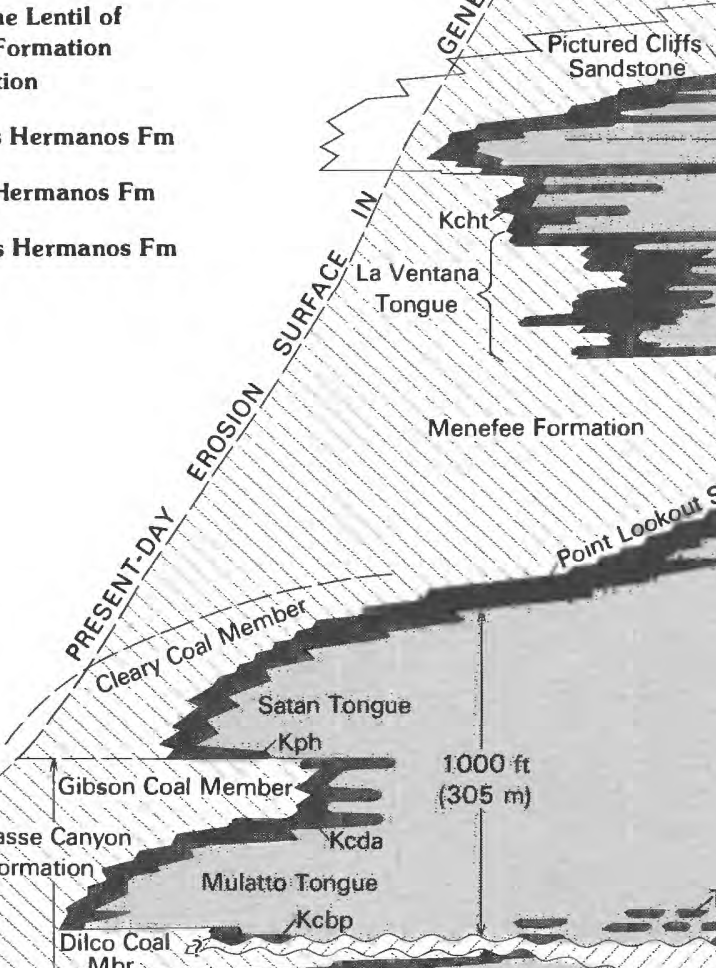

Sictured Cliffs

Upper shale mbr

Farmington Ss Mbr

Lower shale mbr

ruitland

ormation

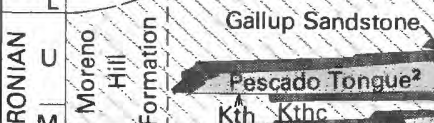

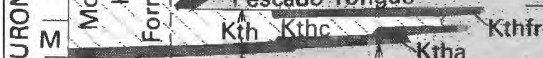

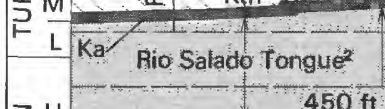

$z_{\leq} \cup \longrightarrow \frac{1}{450} \mathrm{ft}(137 \mathrm{~m})$

Twowells Tongue (Kdt)

Mulatto: Tongue
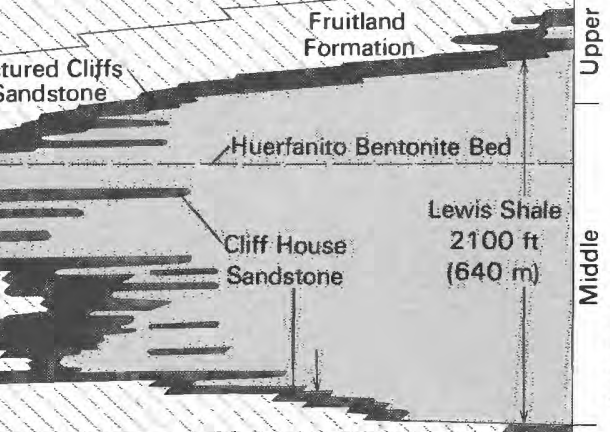

Leing

Lewis Shale

$2100 \mathrm{ft}$

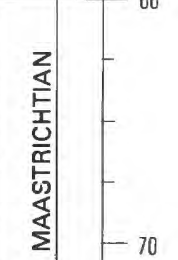




\section{BRIDGE CREEK LIMESTONE MEMBER}

The Bridge Creek Limestone Member of the Mancos Shale, which is about $60 \mathrm{ft}(18 \mathrm{~m})$ thick, consists of interbedded calcareous shale and argillaceous limestone. It is a widespread unit throughout the area, and its contacts are well defined on geophysical logs by the increase in resistivity (deflection to the right) and decrease in gamma-ray radiation (deflection to the left). This is due to less clay content than in overlying and underlying shale units. If the lithology wasn't known, the Bridge Creek could be misidentified on the $\operatorname{logs}$ as a sandstone unit. The lower contact is marked by a prominent bentonite bed. This unit was formerly known as the Greenhorn Limestone Member; the name Bridge Creek Limestone Member was recently applied because it more accurately relates the unit to the Bridge Creek Member of the Greenhorn Limestone near Pueblo, Colo. (Huffman, 1987; Kirk and others, 1988).

\section{UNNAMED SHALE MEMBER}

An unnamed shale member, which is $200-300 \mathrm{ft}$ $(60-90 \mathrm{~m})$ thick, separates the Bridge Creek Limestone Member from the overlying Juana Lopez Member. This unnamed member consists of dark-gray to black, calcareous shale, which contains several prominent bentonite or other marker beds. Variations in calcium carbonate content are indicated by changes in response on resistivity logs. Higher resistivities (excursions to the right) indicate greater carbonate content. The relatively high gamma-ray radiation of parts of this shale member compared with other parts of the Mancos Shale suggests that these parts are richer in organic matter and may be hydrocarbon source rocks.

\section{JUANA LOPEZ MEMBER}

The Juana Lopez Member of the Mancos Shale, which is referred to as the Sanastee Sandstone Member of the Mancos by some industry workers, consists of about $100 \mathrm{ft}(30 \mathrm{~m})$ of interbedded shale, siltstone or very fine grained sandstone, and calcarenite. It is very fossiliferous and contains late Turonian fossils of two or three molluscan fossil zones (Dane and others, 1966). The unit was correlated into this part of the basin from the south, where the upper and lower contacts of the member are better defined on SP and resistivity logs. In the northern part of the San Juan Basin, the Juana Lopez is more difficult to define on logs.

\section{UNCONFORMITY IN LOWER PART OF MANCOS SHALE}

An unconformity in the lower part of the Mancos Shale, which is commonly referred to as the basal Niobrara unconformity, was projected between marker beds from the south-central part of the basin, where an angular relationship is present and discontinuous sandstone units (Tocito Sandstone Lentil of the Mancos) lie above the unconformity (fig. 2) (Penttila, 1964; McCubbin, 1969; Molenaar, 1973). As much as $300 \mathrm{ft}$ $(90 \mathrm{~m})$ of uppermost Turonian-lowermost Coniacian strata (Gallup Sandstone interval) is apparently truncated or abruptly thins across a 15-30-mi- (24-48$\mathrm{km}$-) wide, northwest-trending band in the central San Juan Basin. There is no apparent angular truncation in the northern part of the San Juan Basin, and the position of the unconformity, shown as at the top of the Juana Lopez, is queried on the cross sections. It may be related to a low stand of sea level and, in this part of the basin, may be represented by a nondepositional hiatus. Physical evidence of this unconformity has not been reported from exposures in the Durango area.

\section{REMAINING PART OF MANCOS SHALE}

A 400-500-ft- (122-152-m-) thick interval above the unconformity is characterized by greater resistivity on logs. This interval is interpreted to consist of interbedded shales of variable carbonate content and possibly very fine grained sandstone or siltstone. The lowermost part is equivalent to the Tocito Sandstone Lentil of the Mancos, which is the main reservoir of the oil fields in the south-central part of the San Juan Basin. No recognizable Tocito is present on the cross sections in this part of the basin. At least part of the remaining 400-500-ft interval is equivalent to the $\mathrm{El}$ Vado Sandstone Member of the Mancos, which was named by Landis and Dane (1967) for a 100-ft- (30 m) thick section of interbedded sandstone and shale that crops out on the east side of the San Juan Basin. Fassett and Jentgen (1978) extended the El Vado Member into the subsurface at Blanco Tocito, South field $35 \mathrm{mi}(56 \mathrm{~km})$ south of the Colorado-New Mexico border. We think that it is not warranted to extend the El Vado terminology into the Colorado part of the San Juan Basin because (1) much of the El Vado interval designated by Fassett and Jentgen is calcareous shale in this part of the basin, and (2) there is no indication of sandstone in this part of the section in exposures near Durango (Zapp, 1949). The calcareous shale in this part of the section better fits as an equivalent of the Smoky Hill Shale Member of the Niobrara Formation of southeastern Colorado. 
It should be noted that the top of various highresistivity "kicks" that occur in the upper part of this $400-500-\mathrm{ft}(122-152-\mathrm{m})$ interval were reported in the early years as the top of the Gallup Sandstone by some workers in the San Juan Basin. The Gallup Sandstone actually is below the unconformity and occurs only in the southern part of the San Juan Basin (Molenaar, 1973).

The remaining major part of the Mancos Shale consists of less calcareous shale that, in its upper part, grades into the overlying Point Lookout Sandstone; the bounding lithologies near the contact consist of interbedded sandstone and shale with sandstone content increasing upward. Thus, the placement of the contact is arbitrary and commonly depends on the sensitivity of the $\log$ response. Some workers may place the contact as much as $200 \mathrm{ft}(60 \mathrm{~m})$ lower than that shown on the cross sections.

\section{TIME MARKER BEDS IN MANCOS SHALE}

The numerous time marker beds, which were already discussed, show parallelism in the lower part of the Mancos, but the upper-middle part shows marked basinward (northeast) depositional dip. In relation to higher time marker beds in the upper part of the Mancos, which are assumed to have been almost flat when deposited, the dipping marker beds or clinoforms represent the slope of the basin (after compaction). The steepest dipping time marker beds, which are between wells 18 and 19 on cross section $B-B^{\prime}$, dip about $0.6^{\circ}$ or $55 \mathrm{ft} / \mathrm{mi}(10 \mathrm{~m} / \mathrm{km})$.

\section{POINT LOOKOUT SANDSTONE}

The Point Lookout Sandstone is a regressive coastal sandstone that rises in stratigraphic position as it progrades from southwest to northeast across the San Juan Basin. The formation consists of interbedded very fine grained sandstone and shale in the lower part and grades upward into generally massive fine-grained sandstone. This is indicated on the logs by the upward increase in resistivity (less clay content and fewer shale interbeds) and the upward decrease in gammaray radiation. The upper contact is well marked by the generally abrupt change from massive sandstone to the overlying shaly and coaly rocks of the Menefee Formation. In some areas, however, the Point Lookout sequence is different. Zech and Wright (1989) noted that the Point Lookout changes from a linear strandplain to a delta-dominated deposit from west of Durango to the Piedra River area $15 \mathrm{mi}(24 \mathrm{~km})$ to the east. In that area, the character of the upper part of the
Point Lookout changes from thick, laterally continuous, massive sandstone to thinner, discontinuous sandstones separated by carbonaceous shales.

\section{MENEFEE FORMATION}

The Menefee Formation consists of carbonaceous shale, siltstone, sandstone, and coal. The sediments of the Menefee were deposited in back-barrier-swamp and coastal-plain environments and, to the southwest, the middle part grades to upper coastal-plain and alluvial-plain environments. The Menefee grades seaward (northeastward) into coastal sandstones of the Point Lookout and Cliff House Sandstones. In the northeasternmost part of the San Juan Basin (cross section $C-C^{\prime}$ ), it grades entirely into marine deposits of the combined Point Lookout and Cliff House Sandstones, there called the Mesaverde Formation. The upper contact of the Menefee is placed at the base of a thick marine sandstone (Cliff House), if present, or at the change from the spiky log character of the carbonaceous section below to the more correlatable thin sandstone and shale section of the marine Lewis Shale above. The log response of the Menefee Formation is characterized by abrupt changes in resistivity and gamma-ray radiation that are generally laterally discontinuous in contrast to the log response of the underlying and overlying marine rocks.

\section{CLIFF HOUSE SANDSTONE}

The Cliff House Sandstone is a coastal sandstone unit composed of sediments that were deposited as the seaway transgressed to the southwest. As shown on the cross sections, the Cliff House Sandstone is restricted to the thicker, more massive sandstone bodies immediately overlying the Menefee Formation. Some workers, however, place the top of the Cliff House Sandstone at the top of a transition zone of interbedded sandstone and shale about $400 \mathrm{ft}(120 \mathrm{~m})$ above the Menefee (Zapp, 1949). On the cross sections, this interval is labeled "Lewis Shale-Cliff House Sandstone transition." In tracing this zone to the south, the lower part grades into the massive sandstones of the Cliff House, but the upper part loses the sandstone interbeds and better fits in the Lewis Shale (C.M. Molenaar, unpub. data, 1988). Two anomalous sandstone buildups, which apparently are offshore-bar sandstones, are present in the lower part of this $400-\mathrm{ft}$ - (120-m-) thick zone in well 32 on cross section $C-C^{\prime}$. Within much of the northern San Juan Basin, the Cliff House, as used here, is poorly 
developed. Where present, it consists of onlapping shinglelike wedges that rise in stratigraphic position to the southwest.

\section{LEWIS SHALE}

The Lewis Shale, which is a thick dominantly shale formation, is composed of sediments that were deposited offshore as the seaway again transgressed and regressed across the northern two-thirds of the San Juan Basin. Like the Mancos Shale, it contains numerous time marker beds. The Huerfanito Bentonite Bed, which was used as a datum for all the sections, is a prominent marker bed that can be correlated throughout its extent in the San Juan Basin (fig. 2) (Fassett and Hinds, 1971). The time marker beds are generally parallel, but a slight basinward (northeast) depositional dip is indicated.

The contact of the Lewis Shale with the overlying Pictured Cliffs Sandstone, like the Mancos-Point Lookout contact, is gradational, and the placement of the contact over several hundred feet is arbitrary.

\section{PICTURED CLIFFS SANDSTONE}

The Pictured Cliffs Sandstone is a regressive coastal sandstone that was associated with the final retreat of the Western Interior sea from the San Juan Basin area. Like the Point Lookout Sandstone, it rises markedly in stratigraphic position as it progrades to the northeast. In places it intertongues with the underlying Lewis Shale and the overlying Fruitland Formation. Consisting of interbedded very fine grained sandstone and shale in the lower part, the Pictured Cliffs grades upward into massive fine-grained sandstone. The SP log response of the Pictured Cliffs is greatly attenuated, probably because of clay content. The gamma-ray log responses are also somewhat attenuated if compared to the response in the Point Lookout. The contact with the overlying Fruitland Formation is based on the log-character change of the more varied lithologies in the Fruitland. Commonly, there is a thick coal bed immediately overlying the Pictured Cliffs as indicated by a sharp increase in resistivity on the logs.

\section{FRUITLAND FORMATION}

Like the Menefee Formation, the Fruitland is composed of sediments that were deposited in backbarrier-swamp and coastal-plain environments. It consists of carbonaceous shale, siltstone, sandstone, and coal. Fassett (1986) reported that the coal beds are much thicker and more extensive in the Fruitland than in the Menefee. For more detailed information on the character and distribution of the Fruitland coals, see Sandberg in Chapter D of this professional paper (Sandberg, 1990).

The contact of the Fruitland and overlying Kirtland Shale is usually placed at the top of the highest coal bed or carbonaceous shale by most workers in the San Juan Basin (Fassett and Hinds, 1971). This is difficult to ascertain on logs at the scale used, but because the contact is generally associated with the top of a sandy interval, the latter criterion was used and the contact is queried on all the sections. The log response of the Fruitland Formation, like that of the Menefee Formation, is characterized by abrupt changes in resistivity and gamma-ray response. In this part of the basin, the SP log response is greatly attenuated.

\section{KIRTLAND SHALE}

The Kirtland Shale consists of nonmarine sandstone, siltstone, and mudstone that resulted from deposition on an alluvial plain. It is divided into three units called, in ascending order, the lower shale member, Farmington Sandstone Member, and upper shale member. The two shale members are informal units. The lower shale member is apparent on most SP and resistivity logs, although the upper contact shifts in stratigraphic position. The Farmington Sandstone Member is a thick interval of sandstone and shale bodies. Beds within the member do not seem to be correlatable and are apparently discontinuous. The contact with the overlying upper shale member, where present, is highly questionable. Because of the poor log definition, the discontinuous beds of sandstone, and the possibility that it may not be a mappable unit, the upper shale member is shown only in limited areas on the cross sections. Fassett and Hinds (1971) did not recognize the upper shale member as a mappable rock unit.

\section{TERTIARY ROCKS}

Undivided Tertiary rocks unconformably overlie the Kirtland Shale. These rocks are included in the Animas Formation in most of the area of the cross sections. The Ojo Alamo Sandstone, which is a thick sandstone unit throughout much of the New Mexico part of the San Juan Basin, is present at the south end of cross sections $B-B^{\prime}$ and $C-C^{\prime}$, probably the eastern twothirds of $E-E^{\prime}$, and possibly in well 41 on $D-D^{\prime}$. Its presence is queried on the sections because of 
difficulties in distinguishing it from sandstones in the Animas Formation on the well logs. Fassett and Hinds (1971), however, showed the Ojo Alamo to be present in the areas shown on the cross sections. The Ojo Alamo pinches out northward by truncation or depositional pinchout. Its northward limit was shown by Fassett and Hinds (1971, fig. 9). The Animas Formation consists of volcanogenic sandstone, conglomerate, and variegated shale. In outcrops from Durango southwest toward the New Mexico border, the Animas contains a lower member, the McDermott, which is latest Cretaceous in age. This member probably extends into the northern area of the cross sections, but it could not be identified on geophysical logs.

It is difficult or impossible to ascertain the contact between the Kirtland Shale and the overlying Tertiary rocks (except for the Ojo Alamo Sandstone) on geophysical logs. Detailed well-sample examination or palynological sampling would be necessary to determine the contact. In outcrops, however, it is easier to pick the contact because of the volcanogenic and conglomeratic character of the Tertiary rocks. The contact shown on the cross sections is highly questionable and is based on limited outcrop control and projection of isopach trends of underlying rocks as shown by Fassett and Hinds (1971).

\section{POSTDEPOSITIONAL FEATURES}

Postdepositional features observed on the cross sections are generally subtle. With the numerous time marker beds that are correlated and the vertical exaggeration of the cross sections, however, some features are apparent.

\section{DIFFERENTIAL COMPACTION}

Differential compaction features occur in parts of the stratigraphic section that contain lithologies of variable compactibility, such as lenticular sandstone bodies laterally adjacent to shale or coal units. The most obvious differential compaction feature occurs in the Menefee Formation on cross section $C-C^{\prime}$ between wells 28 and 30 . A thick channel sandstone in the middle of the Menefee in well 29 is laterally adjacent to a shale and coal-bearing section in wells 28 and 30 . The differential compaction and compensating deposition seems to have occurred during deposition of the overlying $200 \mathrm{ft}(60 \mathrm{~m})$ of strata.

\section{FAULTS}

Normal faults, which result in part of the stratigraphic section being cut out, can be recognized by abrupt convergence of time marker beds between wells. Some convergences, however, are progressive and are due to depositional thinning. The only faults definitively recognized on the cross sections are at about $6,900 \mathrm{ft}\left(2,103 \mathrm{~m}\right.$ ) in well 39 (cross section $D-D^{\prime}$ ) and $7,520 \mathrm{ft}\left(2,292 \mathrm{~m}\right.$ ) in well 23 (cross section $\left.C-C^{\prime}\right)$, where $30 \mathrm{ft}(9 \mathrm{~m})$ of stratigraphic section is missing in both wells.

\section{PALEOSTRUCTURE}

Paleostructural effects shown on the cross sections are very subtle and probably represent small differences in subsidence. The difference in thickness of the interval between the Bridge Creek Limestone Member and the Huerfanito Bentonite Bed is the result of subtle paleostructure. No patterns can be recognized, but there is a suggestion of early growth of the Ignacio anticline near the intersection of cross sections $C-C^{\prime}$ and $D-D^{\prime}$.

\section{GAS RESERVOIRS AND PRODUCTIVITY}

Part of the Southern Ute Indian Reservation is within the large San Juan Basin gas field, which produces from Cretaceous rocks and is the second largest gas field in the conterminous United States. Although the Colorado part of the basin does not have the productivity of the larger New Mexico part, significant gas production and reserves do occur in this northern, deeper part of the basin (Irwin, 1983). The initial production rates and producing or perforated intervals are shown for wells on the cross sections. It is beyond the scope of this discussion to cover the petroleum aspects of the Southern Ute Indian Reservation lands. However, because the area covered by the cross sections includes several gas pools of the Ignacio Blanco field and the well logs on the cross sections include the reservoirs, a brief discussion follows.

The gas production within the entire basin is in the structurally low part of the basin and is considered to be controlled largely by stratigraphy and hydrodynamics. However, the broad Ignacio and Bondad anticlines or structures on the Southern Ute lands are important in focusing production in the area. The main producing sandstone reservoirs are in the Mesaverde Group, primarily the Point Lookout Sandstone; the Dakota Sandstone; and to a lesser extent, the Pictured 
Cliffs Sandstone. In addition to the conventional sandstone reservoirs, significant coal-bed methane production is currently being developed in coal beds of the Fruitland Formation (Fassett, 1988).

The main reservoir in the Dakota Sandstone is the lower fluvial part, which is coarser grained than the transitional and marine sandstones above (Bowman, 1978a). Harr (1988) called the lower fluvial complex the Burro Canyon Formation. An uppermost marine shelf sandstone, referred to as Dakota "A" sandstone by Harr (1988) and Bowman (1978a), is a secondary reservoir. The cumulative production from the Dakota in this part of the basin through 1986 was 233.8 bilkion cubic feet (BCF) of gas (Harr, 1988).

The Point Lookout Sandstone is the main producing reservoir in the Mesaverde pool. Channel sandstones in the Menefee Formation probably contribute less than 10 percent of the total Mesaverde production, and the Cliff House Sandstone contributes even less (Bowman, 1978b). The Cliff House Sandstone is best developed near the southwest end of cross section $A-A^{\prime}$, where it is productive. Although the area of production from the Point Lookout covers most of the basinal area, the best production occurs along a 3-4-mi- (2-6-km-) wide belt between the southern part of T. 34 N., R. 10 W., to the New Mexico State line in T. 32 N., R. 7 W. (Harr, 1988). The cross sections show the best sandstone development in the Point Lookout along this belt. The cumulative gas production from the Mesaverde Group through 1986 was 526.6 BCF (Harr, 1988).

The cumulative gas production in the Ignacio Blanco field from the combined Pictured Cliffs Sandstone and Fruitland Formation through 1986 was 57.6 BCF (Harr, 1988), which is only 10-11 percent of the Mesaverde production. The producing area of the Pictured Cliffs and Fruitland is much smaller, much of it being on the Ignacio and Bondad structures (Craney, 1978). The Pictured Cliffs was formerly considered to be the main reservoir of the combined formations, and lenticular channel sandstones and coal of the Fruitland were considered to be secondary reservoirs, but Harr (1988) believed that the Fruitland coal contributed the major part of the gas. Coal-bed methane from Fruitland coal beds is now estimated to contain 4 trillion cubic feet of recoverable gas in the Ignacio Blanco field (Harr, 1988).

\section{REFERENCES CITED}

Bowman, K.C., 1978a, Ignacio Blanco Dakota (gas), in Fassett, J.E., ed., Oil and gas fields of the Four Corners area: Four Corners Geological Society, v. 1, p. 131-132. 1978b, Ignacio Blanco Mesaverde (gas), in Fassett, J.E., ed., Oil and gas fields of the Four Corners area: Four Corners Geological Society, v. 1, p. 137-139.

Craney, D.L., 1978, Ignacio Blanco Fruitland-Pictured Cliff, in Fassett, J.E., ed., Oil and gas fields of the Four Corners area: Four Corners Geological Society, v. 1, p. 134-136.

Dane, C.H., Cobban, W.A., and Kauffman, E.G., 1966, Stratigraphy and regional relationships of a reference section for the Juana Lopez Member, Mancos Shale, in the San Juan Basin, New Mexico: U.S. Geological Survey Bulletin 1224-H, 15 p.

Fassett, J.E., 1986, The non-transferability of a Cretaceous coal model in the San Juan Basin of New Mexico and Colorado, in Lyons, P.C., and Rice, C.I., eds., Paleoenvironmental and tectonic controls in coal-forming basins in the United States: Geological Society of America Special Paper 210, p. 155-171.

Fassett, J.E., ed., 1988, Geology and coal-bed methane resources of the northern San Juan Basin, Colorado and New Mexico: Rocky Mountain Association of Geologists Guidebook, $351 \mathrm{p}$.

Fassett, J.E., and Hinds, J.S., 1971, Geology and fuel resources of the Fruitland Formation and Kirtland Shale of the San Juan Basin, New Mexico and Colorado: U.S. Geological Survey Professional Paper 676, $76 \mathrm{p}$.

Fassett, J.E., and Jentgen, R.W., 1978, Blanco Tocito, South (oil), in Fassett, J.E., ed., Oil and gas fields of the Four Corners area: Four Corners Geological Society, v. 1, p. 233-240.

Harr, C.L., 1988, The Ignacio-Blanco gas field, northern San Juan Basin, Colorado, in Fassett, J.E., ed., Geology and coal-bed methane resources of the northern San Juan Basin, Colorado and New Mexico: Rocky Mountain Association of Geologists Guidebook, p. 205-219.

Huffman, A.C., Jr., 1987, Petroleum geology and hydrocarbon plays of the San Juan Basin petroleum province: U.S. Geological Survey Open-File Report 87-450-B, $67 \mathrm{p}$.

Irwin, C.D., 1983, Stratigraphy and oil and gas production of southwest Colorado, in Fassett, J.E., ed., Oil and gas fields of the Four Corners area: Four Corners Geological Society, v. 3, p. 844-845.

Kirk, A.R., Huffman, A.C., Jr., and Zech, R.S., 1988, Subsurface correlation of Jurassic and Cretaceous rocks having occurrences of uranium, coal, and oil; Mariano Lake-Lake Valley drilling project, northwestern New Mexico: U.S. Geological Survey Oil and Gas Investigations Chart OC-130.

Landis, E.R., and Dane, C.H., 1967, Geologic map of the Tierra Amarilla quadrangle, Rio Arriba County, New Mexico (with description): New Mexico State Bureau of Mines and Mineral Resources Geologic Map 19, 16 p.

McCubbin, D.G., 1969, Cretaceous strike-valley sandstone reservoirs, northwestern New Mexico: American Association of Petroleum Geologists Bulletin, v. 53, no. 10, p. 2114-2140.

Molenaar, C.M., 1973, Sedimentary facies and correlation of the Gallup Sandstone and associated formations, northwestern New Mexico, in Fassett, J.E., ed., Cretaceous and Tertiary rocks of the southern Colorado Plateau: Four Corners Geological Society Memoir, p. 85-110.

Molenaar, C.M., and Baird, J.K., 1989, North-south stratigraphic cross sections of Upper Cretaceous rocks, northern San Juan Basin, southwestern Colorado: U.S. Geological Survey Miscellaneous Field Studies Map MF-2068.

Penttila, W.C., 1964, Evidence for the pre-Niobrara unconformity in the northwestern part of the San Juan Basin: Mountain Geologist, v. 1, no. 1, p. 3-14.

Sandberg, D.T., 1990, Coal resources of Upper Cretaceous Fruitland Formation in the Southern Ute Indian Reservation, southwestern Colorado: U.S. Geological Survey Professional Paper 1505-D, 24 p. 
Zapp, A.D., 1949, Geology and coal resources of the Durango area, LaPlata and Montezuma Counties, Colorado: U.S. Geological Survey Oil and Gas Investigations Preliminary Map 109, scale $1: 31,680$.
Zech, R.S., and Wright, Robyn, 1989, The Durango delta-Complications on a San Juan basin linear-strandplain theme [abs.]: American Association of Petroleum Geologists Bulletin, v. 73, no. 9 , p. 1179-1180. 